\title{
IMPLICATIONS OF GLOBALIZATION FOR MONETARY POLICY
}

\author{
Helmut Wagner \\ University of Hagen
}

Société Universitaire Européenne de Recherches Financières Vienna 2002 


\section{CIP}

Implications of Globalization for Monetary Policy

by Helmut Wagner

Vienna: SUERF (SUERF Studies: 17)

ISBN 3-902109-09-2

Keywords: Globalization, monetary policy

JEL-Classification Number: E5, F0, F4

\section{(C) 2002 SUERF, Vienna}

Copyright reserved. Subject to the exception provided for by law, no part of this publication may be reproduced and/or published in print, by photocopying, on microfilm or in any other way without the written consent of the copyrightholder(s); the same applied to whole or partial adaptions. The publisher retains the sole right to collect from third parties fees payable in respect of copying and/or take legal or other actions for this purpose. 


\title{
Implications of Globalization for Monetary Policy*
}

\author{
Prepared by Helmut Wagner ${ }^{1}$
}

\begin{abstract}
This paper argues that the implications of globalization for monetary policy come mainly through two channels: On the one hand, the many structural changes, which are associated with the globalization process, cause an increase in uncertainty surrounding monetary policy. This leads to an increase in uncertainty about how to interpret macroeconomic data/indicators and about the monetary transmission mechanism. On the other hand, by strengthening the process of global economic integration, the globalization process increases international competition. Thereby, globalization forces market players to make structural adjustments or reforms which change the conditions or constraints under which monetary policy is implemented.
\end{abstract}

JEL Classification Numbers: E5, F0, F4

Keywords: $\quad$ Globalization, monetary policy

Author's e-mail address: $\quad$ Helmut.Wagner@,fernuni-hagen.de www.fernuni-hagen.de/HWagner

\footnotetext{
${ }^{1}$ Professor of Economics, University of Hagen, Germany. A first draft of this paper was written in October and November 2000 when the author was a Visiting Scholar at the Research Department of IMF and at Harvard University.

* This paper first appeared in the IMF Working Paper Series as No. 01/184, November 2001.
} 



\section{Contents}

I. Introduction 7

II. Persisting Effect of Globalization: Increase in Competition 11

$\begin{array}{ll}\text { A. Integration and Competition } & 11\end{array}$

$\begin{array}{ll}\text { B. Effects on Inflation } & 13\end{array}$

C. Policy Implications $\quad 30$

III. Transitory Effect of Globalization: Increase in Uncertainty 33

A. Structural Changes and Uncertainty 33

B. Increase in Uncertainty About the Output and Inflation Gaps 35

C. Increase in the Uncertainty About the Transmission Mechanism 41

D. Policy Implications 45

IV. Conclusion $\quad 53$

Appendix I: Supplementary Remarks on the Basic Model of Section II.B 55

Appendix II: Derivations of Equations (21) and (22) in Section III.C 57

References $\quad 59$

$\begin{array}{ll}\text { SUERF } & 67\end{array}$

$\begin{array}{ll}\text { SUERF STUDIES } & 67\end{array}$ 



\section{Introduction}

Recently, a debate about the implications of globalization and information technology (IT) innovations for monetary policy has begun (see Issing (1999), Brash (2000), Buiter (2000), Ortiz (2000), Remsperger (2000), Solans (2000), Vickers (2000), Wadhwani (2000), and Wagner (2000a, b)).

This paper argues that these implications come mainly through two channels: On the one hand, the many structural changes, which are associated with the globalization process, cause an increase in uncertainty surrounding monetary policy. This leads to an increase in uncertainty about how to interpret macroeconomic data/indicators and about the monetary transmission mechanism (Issing (1999), Solans (2000)). On the other hand, by strengthening the process of global economic integration, the "globalization" process increases international competition. Thereby, globalization forces market players to make structural adjustments or reforms which change the conditions or constraints under which monetary policy is implemented (Wagner (2000a)). This in turn can lead to changes in monetary policy targets, in monetary policy strategies and instruments, and in the optimal institutional framework for monetary policy. Both channels of influence are analyzed in this paper, and some policy implications are drawn. First, however, what is meant by globalization in this paper is defined.

Globalization is a widely used term, but is in fact rather vague. It usually refers to the growing economic interdependence of countries worldwide brought about by the increasing volume and variety of cross-border transactions in goods and services and of international factor flows, and also through the more rapid and widespread diffusion of technology.

A main impetus for this globalization process which has been steadily increasing over the past three decades ${ }^{2}$ has, up to now, been the increased integration and globalization of the financial markets. This has been aided by the abolition of capital controls and by a drastic decrease of transaction costs thanks to new communication and information technologies. ${ }^{3}$

\footnotetext{
${ }^{2}$ Global (world-wide) economic integration, however, only became possible through the breakup of the Soviet Union and the end of the Cold War in the period after 1989.

${ }^{3}$ See e.g. Wagner (1999a). This technological progress is one main component of what is called the "New Economy". The second main component is globalization.
} 
This increased integration and globalization of the financial markets, based on major technological and structural developments ${ }^{4}$ which have lowered the costs of transactions, information and mobility, increasingly exposes private agents and governments to international competition. This process of competition is regarded as being or becoming effective not only in the goods market, but also in the markets for mobile production factors. This exposure to international competition manifests itself in the movement of mobile production factors (nowadays in particular of capital) to countries that offer the highest (riskdenominated) rate of return. This, however, increases a country's costs of maintaining inefficient and overly regulated market structures.

In this paper, the term "globalization" is broken down to some important underlying factors or developments (technological and/or structural changes), and it will be asked how these factors or developments affect monetary policy. Globalization influences monetary policy in different and complex ways. When we speak of the implications of globalization and IT innovations for monetary policy in this paper, we mean the following: do they ease or impede the attainment of the main tasks of monetary policy which are, in particular: (i) prevention of inflation (and deflation); (ii) stabilization of the economy (in cooperation with other economic policies).

Nowadays the prevention of inflation (or price stabilization) is increasingly considered to be the major task of monetary policy by most governments and central banks worldwide. We find strong arguments in this paper which confirm the view that globalization supports monetary policy by tending to reduce inflation. However, as we shall argue, this should not induce central banks to reduce their efforts or alertness to keeping inflation in check. The international competition for mobile capital will force the central banks to stay their course of primarily fighting inflation. However, the many structural changes associated with the globalization process (including the IT

\footnotetext{
4 On the whole, globalization is built and dependent upon structural change on the technological level as well as on the political and socio-cultural level, partly transmitted or enhanced by institutions such as GATT/WTO, and major political shocks such as the breakdown of the communist regimes. These technological and institutional changes or shocks, together, paved the way for global economic integration (global trade, capital flows and diffusion of technology). One should, however, emphasize that the globalization process is still in its evolutionary phase; see for example Okina et al. (1999), Obstfeld (2000) and footnote one above.
} 
innovations, which function as the technological basis of the globalization process $^{5}$ ), lead to an increase in the uncertainty surrounding monetary policy.

The paper is organized as follows. Section II analyzes a channel of influence on monetary policy, which is based on an increase in competition through global economic integration. We show that this channel may explain a tendency towards a decline in inflation (pressures), which is persistent but which may only become fully effective after a time lag. Section III examines channels which derive from an increase in uncertainty that arises from structural changes, in particular from the IT innovations associated with the globalization process. This uncertainty, which tends to be only transitory, is however immediately effective, and covers various fields. For instance, there is uncertainty about how strongly monetary policy should react to output and inflation gaps and how big these output and inflation gaps are. At the end of the Sections II and III, policy implications are analyzed. Section IV concludes the paper.

\footnotetext{
${ }^{5}$ The relationship between globalization and the IT innovations can be understood as a twosided one. The IT innovations not only function as the technological basis for the globalization process, the globalization process itself, by intensifying the international competition process, enhances the innovation process by forcing the economic agents to accelerate their efforts towards technological innovations.
} 



\section{Persisting Effect of Globalization: Increase in Competition}

\section{A. Integration and Competition}

In the Introduction, globalization was defined as a technologically and politically driven process of global economic integration which increasingly exposes private agents and governments to international competition.

We can differentiate between different levels or fields of competition.

- In the private sector (on a microeconomic level), global economic integration, which is effective not only on the financial, but also on the goods and labor market, leads to lower price markups and lower excess wage. "The disciplining effect of global financial markets applies ... also to the private sector, by making it more difficult to sustain unwarranted price markups and nonproductivity driven wage increases" (Citrin and Fischer (2000, p. 27)). This effect of globalization, however, will tend to result in one-time downward shifts in the price level rather than ongoing restraints on the rate of inflation.

- In the state sector (on a macroeconomic level), global economic integration leads to new, fiercer competition on the world market as new countries (competitors) enter the global market. The increased openness to trade and capital flows, based on liberalization and deregulation, particularly on the financial markets, increases the locational or infrastructural competition between regions and countries. This in turn forces governments to reduce inefficiencies.

This paper focuses on this locational competition (the competition in the state sector) since this type of competition tends to result in ongoing restraints on the rate of inflation rather than only one-time downward shifts in the price level. Therefore, this type of competition has more significant implications for monetary policy because, as emphasized in the introduction, prevention of inflation (or price stabilization) is now the central task of monetary policy.

\section{On the concept of locational competition}

Locational competition means that countries and regions have to provide good infrastructure (better infrastructure than competing countries or regions) 
to attract mobile production factors. Good infrastructure increases the incentive for foreign direct investors to invest in this country or region and improves the chances of domestic firms attracting foreign mobile production factors or keeping their own productive factors from moving outward. ${ }^{6}$ Here various so-called locational or infrastructural factors matter, for example on the national level: legal security (property rights, contract enforcement), social security, economic and political stability; and on the regional level: cultural offers or infrastructure, housing, roads, safety etc. In this paper, we concentrate on macroeconomic stability as a key locational factor on the national level. Major indicators or signals of macroeconomic (in)stability are inflation, debt and tax burden (Fischer (1991)).

By reducing these undesired macroeconomic factors to a level which is lower than in competing locations, governments can try to attract mobile capital from other locations and to keep domestic mobile capital (human capital as well as financial and real capital and investment) from moving outward into other countries or regions. In other words, globalization induces stronger locational competition between countries or regions for mobile capital. ${ }^{8}$

\section{Pressures on governments to implement structural reforms}

It is known that governments have an important role to play in creating the conditions that attract foreign direct investment (FDI) and in maximizing the positive contribution that FDI can make to growth and development (UNCTAD (1999)). Globalization in the above sense forces governments to exercise greater fiscal discipline and to ensure sound institutional and political frameworks. In other words, it does "act as a force for stability by limiting the scope for countries to pursue policies that are incompatible with medium-term financial stability" (Citrin and Fischer (2000, p. 27)). Thus, governments feel pressured by the (globalization-driven) locational competition to promote international competitiveness through

\footnotetext{
${ }^{6}$ However, the domestic firms also have to fulfil their own part of the task insofar as they have to supply (comparatively) attractive work conditions and remuneration.

${ }^{7}$ In Iwd (1999) it is reported that a questionnaire survey of 454 German firms, organized by the Confederation of German Industry and of the Society for Promotion of the Protection of Foreign Investments, established that macroeconomic conditions in the form of weak growth and high inflation were the deficiencies most frequently criticized as hindering foreign direct investment by the firms questioned.

${ }^{8}$ On the concept of "locational competition" (Standortkonkurrenz) see in more detail Siebert (1995), (1996), (2000), and Lorz (1997).
} 
macroeconomic stability particularly by lowering taxes, government debt, and inflation (as will be examined in more detail below).

In the following, we concentrate on the effects on inflation, as inflation is the main target variable of monetary policy. We argue that locational competition tends to reduce (trend) inflation directly as well as indirectly. ${ }^{9}$ This may be interpreted as a possible basis for the "new paradigm" view of inflationless growth (which is different from and supplements the one which is based on the argument of ongoing productivity growth). However, as we shall also argue, there are some caveats on this view insofar as there are some trade-offrelationships between the different locational factors or reform costs which have to be considered. After presenting the basic idea, some models and their results are presented.

\section{B. Effects on Inflation}

In the public discussion about globalization, there is an often-used hypothesis which assumes that globalization leads to a systematic decline in inflation; some even speak of the "death of inflation" (Bootle (1996)). To test this hypothesis, various models are analyzed and all the results suggest that globalization may reduce inflation. Most of the models will be discussed in this chapter. One model, however, is discussed in Section III.C because it is based on an increase in uncertainty about the monetary transmission mechanism which is investigated in Section III.C.

\section{The basic model}

We formulate a mainstream Barro and Gordon (1983)-type model of macroeconomic policy and inflation. Policy is assumed to minimize the following quadratic loss function:

$$
E[L(p, y)]=L=E\left\{0,5\left[\left(\pi-\pi^{*}\right)^{2}+b\left(y-y^{*}\right)^{2}\right]\right\}
$$

where $\pi$ and $y$ denote inflation and employment (or output growth) respectively, $\pi^{*}$ and $y^{*}$ are society's most preferred values for inflation and employment (or output growth), and $b$ is the relative weight on fluctuations in these two variables.

\footnotetext{
${ }^{9}$ See also Citrin and Fischer (2000) who argue that an aspect of globalization that is "likely to have a long-lasting influence on inflation is the discipline on domestic financial policies imposed by increased financial market integration" (p. 26).
} 
14 Persisting Effect of Globalization: Increase in Competition

The loss function is minimized under the constraint of an expectationsaugmented short-run Phillips curve

$$
y=y_{n}+c\left(\pi-\pi^{\mathrm{e}}\right)-\varepsilon
$$

where $\varepsilon$ is a supply shock (with mean 0 and variance $\sigma_{\varepsilon}^{2}$ ) and $y_{n}$ can be interpreted as the natural rate of employment (or output growth). It is assumed that $y_{n}<y^{*}$ and (at first) that $c=1$.

Furthermore we add the demand side of our model being represented by

$$
\pi=m+v
$$

where $m$ is the growth rate of money and $v$ is a velocity shock (with mean 0 and variance $\sigma_{v}^{2}$ ).

In addition, we assume rational expectations information so that

$$
\pi^{e}=E\left(\pi \mid y_{n}\right)=E\left(m \mid y_{n}\right)
$$

where $E$ is the mathematical expectations operator.

Then, as is widely accepted in the literature, ${ }^{10}$ we can derive an inflation bias of $b\left(y^{*}-y_{n}\right)$ from the difference between the optimal rate of inflation,

$$
\pi_{\mathrm{O}}=\pi *+[b /(1+b)] \varepsilon
$$

and the discretionary rate of inflation

$$
\pi_{D}=\pi *+b\left(y^{*}-y_{n}\right)+[b /(1+b)] \varepsilon .
$$

For supplementary remarks on this basic model see Appendix I. ${ }^{11}$

\section{Direct effects of integration: The Romer case}

The recent literature has identified openness as one of the countervailing forces that lessen the incentive to inflate. The argument which is originally due to Romer (1993) is that, the more open the economy, the smaller the real benefits of higher output from surprise monetary expansion, and thus the

\footnotetext{
${ }^{10}$ See Persson and Tabellini (1999).

${ }^{11}$ During the last decade, the question has increasingly been raised whether the inflation bias argument has not been overstated or is losing relevance as a substantiation for central bank independence and in general (see Blinder (1998), Vickers (1998), and McCallum (1995, 1997a)), who believe that contemporary central banks target potential output). If this is really the case, it may partly be attributed to the increasing institutional competition (between countries and regions) caused by the globalization process. However, it is likely that even if the inflation bias argument has been overstated or is losing relevance, the underlying problem of dynamic inconsistency is still prevalent, in particular in developing and transitional countries.
} 
lower the equilibrium rate of inflation. As domestic output increases, the terms of trade worsen: the more open the economy, the larger the fraction of foreign goods in domestic consumption, and the greater the welfare loss from the terms of trade loss. In short, more open economies may be blessed with a lower incentive to inflate. ${ }^{12}$

Since globalization goes hand in hand with more open economies, the surprise inflation effect, which induces a lower increase in output, can be interpreted as one effect of globalization that is relevant for monetary policy. In the above model context, this effect would mean that the Phillips curve is steeper $(d \pi / d y=1 / c$ increases). This would reduce the inflation bias:

$$
\pi_{D}^{\text {Romer }}=\pi^{*}+c b\left(y^{*}-y_{n}\right)+\left[c b /\left(1+c^{2} b\right)\right] \varepsilon, \text { where } 0<c<1 . .^{13}
$$

In the following, however, we shall investigate in more detail different models which may also substantiate a decline in inflation but are based on locational competition induced by globalization.

\section{Indirect effects: Implications of an increase in locational competition}

(High) inflation is an undesirable locational factor and a locational disadvantage in a globalized world, ${ }^{14}$ mainly because inflation is regarded as a signal of bad policy and political and economic instability. ${ }^{15}$ As bad policy and political and economic instability are relevant locational factors or disadvantages, this contributes to capital flight in a globalized economy (Wagner (2000a)). The costs of a capital drain stem from the fact that investors and (productive) mobile factors are the basis of economic growth. When firms and mobile capital leave the country (or region), this means a loss of (potential) production, a decrease in the (potential) output, an increase in

${ }^{12}$ Lane (1997) showed that the prediction that more open economies have lower equilibrium inflation rates is true independently of the terms of trade mechanism emphasized by Romer (1993). The mechanism linking the welfare effects of monetary surprises, and hence the incentives to inflate, to openness does not depend on a large-country terms of trade effect but rather is due to imperfect competition and nominal price rigidity in the nontraded sector.

${ }^{13}$ The corresponding output is $y=y_{n}-\left[1 /\left(1+c^{2} b\right)\right] \varepsilon$.

${ }^{14}$ See, for example, the empirical results in Autschbach (1997, pp. 147, 184).

${ }^{15}$ See for example, Shiller (1997) and Mankiw (1999). In addition, it is often believed that (high) inflation may reduce economic growth, even though previous empirical evidence that links inflation with overall economic performance is not particularly robust. Still, some empirical studies are available that show that there has been a negative correlation between the rate of inflation and the rate of economic growth (Fischer (1993), Judson and Orphanides (1996), and Barro (1997)). With high inflation, at very least, intertemporal resource allocation is misguided. In addition, the functioning of financial intermediation, which plays an important role in intertemporal resource allocation, is weakened. 
16 Persisting Effect of Globalization: Increase in Competition

unemployment and a decrease in productivity (particularly if, as is often the case, the most productive factors and the most innovative investors are the most mobile ones). This tendency for capital flight in the case of bad locational factors (such as high inflation) is stronger, the higher the integration and globalization of the financial markets is.$^{16}$ By contrast, the host country (recipient) profits from attracting foreign mobile capital. It profits from technology transfer because foreign direct investment (FDI) allows the labor force in the host country to become better trained. In addition, FDI generates profits and tax revenues in the host country. ${ }^{17}$

Inflation, however, works like taxation. The real effective capital income tax rate rises as inflation increases. ${ }^{18}$ The effects on capital income taxes are a main mechanism by which the tax system becomes nonneutral to inflation. Here, however, we have to differentiate between the short term and the long term. (Physical) capital can be withdrawn from one use, and directed toward another, only gradually. ${ }^{19}$ The fact that capital is thus not very mobile in the short term means that capital income can be a target for redistributive policy (see Wildasin (2000)). Inflation or expansionary (inflation-producing) policy, can be looked at in the same way. That is, inflation can be regarded as a form of source-based capital income tax (see Feldstein (1997)). Over time, however, when there are not favorable conditions, capital flows out of the jurisdiction, causing labor productivity and income to fall. That is, inflation may not only be regarded, as economic theory suggests, as a phenomenon that leads to misallocation of resources, but it may also reduce economic growth. ${ }^{20}$ Therefore, governments, unless they are very myopic, when deciding about structural priorities, will consider the costs of a capital drain and of not being able to attract foreign capital which functions as a source of financing investments and economic growth. ${ }^{21}$ But it may be argued that governments

\footnotetext{
${ }^{16}$ See Berger (2001).

${ }^{17}$ Feldstein (2000). Furthermore the foreign owners of capital can profit from FDI as they can benefit from economies of scale.

${ }^{18}$ See Feldstein $(1997,1999)$. The consequence of an increase in source-based taxation of mobile capital has recently been analyzed by Wildasin (2000), who demonstrates how competition among countries for mobile resources constrains their ability to alter the distribution of income.

${ }^{19}$ In practice, it is costly to add, refurbish or replace plant and equipment. This is also the case with adjustments in the level of employment (see Hamermesh and Pfann (1996)). The adjustment costs, however, vary from company to company, and from asset to asset.

${ }^{20}$ See Fischer and Modigliani (1978), and Wagner (1983).

${ }^{21}$ See also Siebert (2000, p. 30): "The government is confronted with a restricted scope for action as the tax basis shrinks when real capital moves away. Moreover, labor productivity declines when real capital flows out. Thereby, the wage and employment chances decrease. Thereby, the tax basis also shrinks. Governments must consider these potential effects of an exodus of capital when making decisions." (Translation)
} 
and politicians are myopic and therefore, as long as (physical and human) capital is not very mobile in the short term, will tend to neglect this aspect. However, the possibility and attractiveness for capital to fly or move to other locations tends to increase with the degree of international capital mobility, i.e. financial integration. In other words, financial globalization reduces the term during which capital is not very mobile. Hence one can expect that gradually, with the increase in financial integration, even myopic politicians will soon attach greater importance to the target of preventing inflation. They will then show more fiscal discipline insofar as, when adverse demand shocks occur, they produce less conflicts with monetary authorities about releasing monetary restrictions set up to prevent inflation.

Moreover, increasing factor mobility tends to limit the effectiveness and the attractiveness of redistributive, inflationary policies (Wildasin (2000)). This means that there will be fewer conflicting interests between fiscal and monetary policy, so that preventing inflation may become easier for a central bank. In other words, the conditions for price stability policy become more favorable.

Furthermore, as mentioned in the beginning of this section, inflation is regarded by the public as a signal of bad policy and political and economic instability. But not only inflation as the result, also the mere attempt or the inclination to comply with the incentive of raising output (or compensating output losses, from capital drain) by a surprise inflation can be regarded as an indicator of bad policy and economic instability and will consequently be punished by capital drain. Hence one may guess that globalization thereby will gradually reduce the inflation bias.

The above argument suggests that the increase in the costs of inflation represents an effect which takes place only with a certain delay. ${ }^{22}$ We have

\footnotetext{
${ }^{22}$ However, there is also an immediate effect based on the role of currency competition. An increase in the international mobility of portfolio capital leads to stabilization policies (monetary policy, fiscal policy and even wage policy) in the individual countries being subject to greater control by the financial markets. For example, if the central bank of a country does not undertake a price stability orientated policy, whereas the central banks of other countries do, the external value of the currency of this country will decline. If the citizens of this country perceive this devaluation as a signal that the stabilization policy of their country has not been successful and thus lose confidence in this policy, then the government comes under pressure to give up this policy of instability. An example for this is the reorientation of the policy course of the French Government in 1983. In March 1983, France totally revised its economic policy, which during the years before was directed towards stimulation of the internal demand. A continued high inflation rate, increasing current account deficits and increasing foreign debts finally led to a devaluation of the French franc.
} 
18 Persisting Effect of Globalization: Increase in Competition

emphasized that (physical) capital can be withdrawn from one use, and directed toward another, only gradually. In other words, it takes a while until the costs of a capital drain and of the consequent loss of output occur and before a pressure arises which forces a government to install reform measures in order to reduce these costs. Over a certain period of time, globalization may even create inflation-increasing effects as is shown in the following. There we argue that inflation itself can be understood as the result of inefficient structural conditions. ${ }^{23}$ These inefficiencies, which supposedly can only be reduced by (costly) structural reforms, are considered to be the consequence of a (rational) delay of reforms. Therefore, inflation itself (as well as the other locational hindrances mentioned) can be regarded as the consequence of a delay of (or failure to) reform. The macroeconomic effects of the increase in the costs of inflation caused by globalization can be modeled in different ways. Here we only analyze two models. First, we integrate these costs into the supply curve of the basic model (equation (2)) by arguing that the costs of a delay of reforms and of reform unwillingness ${ }^{24}$ rise (model approach I below).$^{25}$ Here we have to consider that there are also costs of implementing reforms. ${ }^{26}$

Besides of this model variant which (like the Romer case) reflects a change in macroeconomic conditions, we also analyze below a second variant which includes changes in the preferences induced by the discernment of the increase in the output costs of inflation (model approach II).

\section{Model approach I: Increase in the costs of a delay of reforms ${ }^{27}$}

In this section, inflation is considered to be the result of inefficient structural conditions. We consider an economy in which the socially desired level of

${ }^{23}$ See Wagner (2000a). This can be traced to a failure to make reforms in areas such as labor market rigidity, or financial and monetary policy aspects, for example inappropriate taxation and government debt or central bank dependency.

${ }^{24}$ Since inflation is a public bad, reform unwillingness should not be regarded as an individual phenomenon but as the result of coordination problems among societal groups.

${ }^{25}$ Another way of modeling this idea within the above basic model structure would be to introduce direct output costs of (higher) inflation (beyond the level of that of competing countries) into the supply function. However, as in the version presented above, this - perhaps surprisingly - does not necessarily strengthen the inflation-reducing effect of globalization found in the Romer case above. The reason is rather simple. In the above time inconsistency (basic model) approach, the output loss caused by (relatively higher) inflation automatically produces an incentive to create an inflation surprise to compensate for the output loss. Consequently, there are two counteracting effects.

${ }^{26}$ See Saint-Paul (1996). While the costs of a delay of reforms may be thought of rising when globalization increases, the costs of implementing reforms may be assumed to be exogenous.

${ }^{27}$ I would like to thank Friedrich Kißmer for suggesting this case to me. 
output can only be reached when government implements reforms $r^{*}$. The de facto implemented reforms $r$ may fall short of $r^{*}$ because reforms are costly for the government. We denote this positive difference $r^{*}-r>0$ as backlog or delay of reform. We suppose that a backlog or delay of reform implies higher unemployment and lower production (see Calmfors (1998)).

The supply function is

$$
y=y^{*}+c\left(\pi-\pi^{\mathrm{e}}\right)-a\left(r^{*}-r\right)-\varepsilon,
$$

where $\left(r^{*}-r\right)=$ "delay of reform", and $y^{*}-a\left(r^{*}-r\right)=y_{n}$.

In this case, for reasons of simplicity, we set $c=1$ and $\varepsilon=0$ and normalize $y^{*}$ to 0 . Based on the arguments above, we assume that globalization, through an increase in locational competition and in capital mobility, in time leads to an increase in production losses caused by a given delay of reform. That is, this aspect of globalization is denoted, in a comparative-static sense, by $d a>0$ (a once-for-all increase in $a$ ).

Economic policy is conducted by two policy actors, the government and the central bank. The government, on the one hand, fixes the level of reforms $(r)$. It minimizes the following loss function:

$$
L^{G o v}=0,5\left(\left(\pi-\pi^{*}\right)^{2}+b\left(y-y^{*}\right)^{2}+z r^{2}\right), \text { where } y^{*}=\pi^{*}=0, b, z>0
$$

We assume that the implementation of reforms is associated with political costs $(z>0)$ for the government.

The central bank, on the other hand, decides about the rate of inflation by minimizing the loss function $L^{C B}$.

$$
L^{C B}=0,5\left(\left(\pi-\pi^{*}\right)^{2}+b_{C B}\left(y-y^{*}\right)^{2}\right), \text { where } y^{*}=\pi^{*}=0, b \geq b_{C B}>0
$$

This loss function does not include $r$ since we assume that the central bank is "independent" and not responsible for the implementation of the reforms ${ }^{28}$ In addition, in analogy to Rogoff (1985), we assume that the central bank might not weigh output stability as highly as the government does $\left(b_{C B} \leq b\right)$. Furthermore, to simplify calculations, we assume in the following that the target levels for inflation and output (in logarithm) are zero $\left(y^{*}=\pi^{*}=0\right)$.

The macroeconomic outcomes depend upon whether the economic policymakers are committed or act in a discretionary way vis-à-vis the public.

\footnotetext{
${ }^{28}$ This assumption is not of significance for the result here.
} 
Furthermore, when monetary policy is discretionary, we have to distinguish between Nash- and Stackelberg equilibria.

\section{Monetary policy rule}

In the case of monetary policy commitment, we do not have to differentiate between whether the reform by the government follows a rule or is discretionary.

With committed monetary policy, on the basis of the model structure above, we get the following solutions:

$$
\begin{gathered}
r_{R}=\frac{a^{2} b}{z+a^{2} b} r^{*} ; 0<r^{R}<r^{*} \\
\pi_{R}=0=\pi^{*} \\
y_{R}=\frac{-a z}{z+a^{2} b} r^{*} ; y_{R}<0=y^{*}
\end{gathered}
$$

From equation (11) we see that a delay of reforms is optimal for the government if there are political costs of the implementation of reforms $(z>0)$. This delay of reforms implies that output lies below its desired level (see equation (13)). From equation (11) we also see that the aspect of globalization considered here (expressed by $d a>0$ ) induces reforms. ${ }^{29}$ Nevertheless, it leads to a loss in output if $z>a^{2} b .{ }^{30}$

\section{Discretionary monetary policy and committed reform ${ }^{31}$}

We assume the following timing of events:

(i) First, the government chooses a policy rule $r$.

(ii) The private actors form inflation expectations.

(iii) Government implements the reforms that were chosen at step 1.

(iv) Finally, the central bank chooses the rate of inflation.

\footnotetext{
${ }^{29}$ This can be seen from the derivation $d r_{R} / d a$ in equation (11).

${ }^{30}$ This can be seen from the derivation $d y_{R} / d a$ in equation (13).

${ }^{31}$ The case of "discretionary monetary policy and discretionary reform", in which we have to distinguish between a Nash-equilibrium and a Stackelberg-equilibrium with leadership of the government, is not analyzed here. The result would not be fundamentally different (Kißmer (2001)). It can be shown however that the above threshold declines when reform is not credible.
} 
This game structure supposes that the government is credible to the private actors and actually implements the plan for reforms chosen in step (i). The government considers that its choice of reform has influence on the inflation expectations and the rate of inflation chosen by the central bank. The government thus behaves like a Stackelberg leader vis-à-vis the public and the central bank.

From the first order condition of the central bank's optimization problem, we get

$$
\pi=\pi^{\mathrm{e}}=a b_{C B}\left(r^{*}-r\right)
$$

We see that the private actors only expect inflation just when there is a delay of reform. The reason is that the central bank has a too ambitious output target $\left(y^{*}=0>y_{n}=-a\left(r^{*}-r\right)\right)$. Hence, in the case of a delay of reform and discretionary monetary policy, the central bank has an incentive to raise the output by creating a surprise inflation.

However, the extent of reforms is not exogenously given but is determined by the government. By inserting $(14,15)$ into the loss function of the government, we can calculate inflation and output, after determining the optimal level of reforms. The solutions of the Stackelberg equilibrium (SR) with committed reform are

$$
\begin{gathered}
r_{S R}=\frac{a^{2}\left(b+b_{C B}{ }^{2}\right)}{z+a^{2}\left(b+b_{C B}{ }^{2}\right)} r^{*} ; 0<r_{R}<r_{S R}<r^{*} \\
\pi_{S R}=\frac{a b_{C B} z}{z+a^{2}\left(b+b_{C B}{ }^{2}\right)} r^{*} ; \pi_{S R}>0=\pi_{R} \\
\mathrm{y}_{S R}=\frac{-a z}{z+a^{2}\left(b+b_{C B}{ }^{2}\right)} r^{*} ; y_{R}<y_{S R}<0
\end{gathered}
$$

From equation (16) it follows that, with discretionary monetary policy, a delay in reform is optimal $\left(r_{S R}<r^{*}\right)$, if there are political costs of an implementation of reforms $(z>0)$. However, the extent of the delay of reform is smaller compared with the case of a committed monetary policy; hence the output is higher.

From equation (17) we see that, with discretionary monetary policy, a delay of reform leads to higher inflation $\left(\pi_{S R}-\pi_{R}>0\right){ }^{32}$

${ }^{32}$ When there is a delay of reform (which exists when $z>0$, see equation (16)), the output level remains below the desired level. Therefore, there is an incentive for the discretionary monetary policy to increase the output by producing a surprise inflation. Since this is anticipated by the private actors and the government, the monetary policy contains an inflation bias. 
Which effect does this aspect of globalization have here? The results show that, as in the case of a committed monetary policy, globalization leads to an increase in reforms. Whether it leads to so-called "New Economy effects" $(d \pi / d a \leq 0<d y / d a)$, depends upon the extent of the reforms implemented, or, in other words, upon the degree of reform aversion $z$. If $z<a^{2}\left(b+b_{C B}{ }^{2}\right)$, globalization creates New Economy effects, i.e. raises production and lowers inflation. If, $z>a^{2}\left(b+b_{C B}{ }^{2}\right)$, however, globalization (in the above sense) leads to lower production and higher inflation.

\section{Interim conclusion}

In this comparative-static model variant, we have shown that globalization (denoted by its effect of an increase in the costs of a delay of reforms, i.e. of $d a>0$ ) decreases inflation if $z<a^{2} x$, where $x=b+b_{C B}{ }^{2}$ in the above case. However, if $z>a^{2} x$, globalization can create undesired macroeconomic effects, i.e. it can increase inflation and decrease output. Above, however, we have introduced globalization as a dynamic process. Therefore, one may be inclined to assume that globalization gradually increases the output costs of a delay of reforms (i.e., of $a$ ) ${ }^{33}$ so that eventually (apart from extreme cases, ${ }^{34}$ where $z \rightarrow \infty$ ) the condition $z<a^{2} x$ will be effective and inflation will decline. This, however, can not be derived from the above model because in every case, when $a$ increases, the extent of the backlog or delay of reforms $\left(r^{*}-r\right)$ declines. However, what can reasonably be assumed, is that over time the general understanding of the necessity of reforms increases so that the political costs of reforms $(z)$ decrease. This eventually would have the consequence that the condition $z<a^{2} x$ will be effective and inflation will decrease. Alternatively one can also think of other changes in the loss functions of the government, of the society or of the central bank. This will be described in the following.

\section{Model Approach II: Changes in preferences and institutions}

In the above models (in the Romer case as well as in the case of costs of a delay of reforms) we have denoted the consequences of globalization by

33 The stronger the global economic integration is, the stronger will be the pressure of competition, and the greater will then be the output loss of a delay of reforms (expressed by high inflation), i.e. the larger will be $a$.

${ }^{34}$ The reform unwillingness in a country can be derived from country-specific coordination problems with respect to the means of reform and to the corresponding distribution of the reform costs. It thus is the result of specific social conditions; see e.g. Alesina and Drazen (1991), Cukierman, Edwards and Tabellini (1992), Drazen (2000), Chang (2001). 
a change in the restrictions on the optimization problem. However, we can also denote them by a change in the loss function. For instance, one can model the consequences of globalization as a gradual understanding of the necessity of making reforms reacting to the more and more costly inflation (if a threshold ${ }^{35}$ has been exceeded). This can be reflected in a decrease of the political costs of or the aversion to reforms $(z)$, as mentioned above. It, however, can also find expression in other changes of preferences. This has been described in Wagner (2000a) where, by extending the basic model above, different cases have been analyzed, assuming that the inflation-costincreasing effect of globalization can be modeled alternatively as leading to

- a higher aversion to inflation

- a lower preferred inflation rate

- an additional cost factor in the loss function of the central bank or of the government

- an additional cost factor in the loss function of the society.

It is shown there that although the consequences differ in detail, depending on the modeling assumptions, all these cases come to the result that globalization decreases inflation. In most of the cases, globalization also reduces the inflation bias of a society. And in the last case, it even leads to a systematic undercutting of the socially desired rate of inflation. Here, however, we shall only briefly analyze one of these cases and then go on to deal with some institutional supplements (namely central bank independence and exchange rate pegging), which have been extensively used in practice over the last decade.

\section{Case (A): A higher aversion to inflation}

We can assume that the facts of the higher costs of inflation and lower benefits of surprise inflation described above are going to be understood and internalized by society, leading to a higher aversion to inflation, i.e. a lower $b$, denoted $b^{\prime}$. This is reflected in a rising acceptance among the public that the key objective of monetary policy should be to deliver low inflation, and that fiscal policy should not rely on the inflation tax. A higher aversion to inflation in turn leads to an inflation reduction by reducing the inflation bias. That is, the equilibrium inflation rate will be

$$
\pi_{D}^{\text {case } A}=\pi^{*}+b^{\prime}\left(y^{*}-y_{n}\right)+\left[b^{\prime} /\left(1+b^{\prime}\right)\right] \varepsilon, \text { where } b^{\prime}<b^{36}
$$

\footnotetext{
${ }^{35}$ In the model approach $\mathrm{I}$, the threshold was expressed by the condition: $z=a^{2} x$.

${ }^{36}$ The corresponding output is $y=y_{n}-\left[1 /\left(1+b^{\prime}\right)\right] \varepsilon$.
} 
This can easily be derived from the basic model above. ${ }^{37}$

Now, to strengthen this effect, various institutional ways to further reduce the inflation bias can be taken into consideration. Two of them have been implemented in many countries during the last decade(s). These are central bank independence and exchange rate pegging.

\section{Case (B): Implementation of Central Bank Independence (CBI)}

In the 1990s, numerous countries provided their central banks with greater legal independence from the government. This trend towards increased central bank independence has been witnessed in both industrialized and developing countries. Within the former socialist countries of Central and Eastern Europe, economic transition has also been accompanied by substantial central bank reforms granting greater 'goal' and 'instrument' independence. ${ }^{38}$

Usually central bank independence is interpreted in the following way: societies attribute independence to central bankers who have the same loss function as the societies but a different personal value of $b$ (a lower $b$, denoted $b$ "). The appointed central bankers then set monetary policy according to their own preferences. From the basic model structure above, this gives the equilibrium outcome:

$$
\pi_{C B I}=\pi^{*}+b "\left(y^{*}-y_{n}\right)+[b " /(1+b ")] \varepsilon .
$$

However, this comes with the disadvantage of higher output or employment volatility. From the above model structure one can derive the following patterns of output or employment:

$y_{D}=y_{O}=y_{n}-[1 /(1+b)] \varepsilon$ with discretion and with the optimal state-contingent policy rule,

whereas with central bank independence $y_{C B I}=y_{n}-[1 /(1+b ")] \varepsilon$.

\footnotetext{
${ }^{37}$ One comes directly to the result by looking at equation (6) in Appendix I.

${ }^{38}$ In these former socialist countries, however, the question sometimes arises whether the delegation of independence to the central bank is actual or only legal (see Cukierman (1998)). If it is only "legal", i.e. only exists on paper, as is still the case in many transitional countries, there is a danger that it will not only be ineffective but even counterproductive (Wagner (1999c)).
} 
This means that output or employment volatility is greater with central bank independence. ${ }^{39}$ Nonetheless, if globalization leads to a higher aversion to inflation and hence produces, for example, the inflation rate in equation (19), one may conclude that globalization creates here the same disciplinary effect as central bank independence. By comparing equations (19) and (19') one may, against the background of the costs of central bank independence described above, conclude that central bank independence is then not needed anymore, at least not in its function as a shield against the time-inconsistency problem.

Globalization here has the same qualitative impact on the inflation rate as central bank independence has. In case $b^{\prime}=b "$, the results coincide exactly, so that central bank independence appears to become superfluous.

However, this interpretation is incorrect, at least if we stay within the model of the world above. As long as society has $b^{\prime} \neq 0$ (i.e., has some aversion to inflation), the optimal $b$ " (the appointed central banker's personal value of $b$ ) will always lie below $b^{\prime}$. The solution can still be improved by central bank independence, because the optimal (central banker's) $b$ " is a function of $b$ '. Globalization in the sense of a reduction of $b$ ' does therefore not replace central bank independence, but increases the degree of optimal inflation aversion of the central banker. However, if we depart from the above model and no longer measure central bank independence against $b$, but against the degree of self-assertion of the central bank, it may in fact be possible to establish the above hypothesis of a decline in the degree of optimum central bank independence with ongoing globalization in the above meaning of equation (19); see Eijffinger and Hoeberichts (1998) and Wagner (2000a, pp. 379-80).

Moreover, one may argue that the institutional competition, which was described above as a characteristic of globalization, tends to make institutions such as central bank independence into a "must" for a nation in order to be able to sell bonds on the international financial markets, at least at a "reasonable"

\footnotetext{
${ }^{39}$ This could, however, be reduced by a partial reduction of central bank independence, for instance by implementing an overriding mechanism (see Lohmann (1992)). Here, the government appoints a conservative central banker but threatens to terminate the contract if deviations from the target inflation become too large. Moreover, central bank independence is found to reduce electorally-induced volatility of output or employment (see Alesina and Gatti (1995); and Lippi (1998), who provides evidence that could support this proposition). This aspect of a reduction in the political economy cycle may also explain why the above hypothesis of greater output or employment volatility with central bank independence has not been proven in many empirical studies.
} 
price. Central bank independence can be regarded as a kind of institutionalized rating, as a quality label for transparency and financial solidity. This increases the credibility of macroeconomic polices, thereby alleviating capital borrowing on international capital markets and decreasing its costs.

\section{Case (C): Exchange rate pegging}

Another method of achieving price stability (more quickly), which is frequently used by small countries in particular, is to peg the value of its currency to that of a large, low-inflation country. The reasons for doing so are as follows: When monetary policy is set with full discretion, there can be an inflationary bias. A central bank which wants to combat inflation can commit more credibly by fixing the exchange rate to that of a large, low-inflation country. This creates low(er) inflation expectations, and thereby a low(er) level of inflation for any given level of output.

However, while in 1991, 78 percent of all IMF member countries had some degree of fixed or pegged exchange rate regime (hard or soft peg), this number had dropped to 58 percent by 1998 (Fischer (2001)). In particular, countries have moved away from the middle ground of pegged but adjustable fixed exchange rates (soft pegs) towards the two corner regimes of either flexible exchange rates or hard pegs, i.e. a fixed exchange rate supported, if necessary, by a commitment to give up altogether an independent monetary policy. The reason is that the experiences of the 1990s have shown that, although adhering to a pegged exchange rate regime can be a successful strategy for controlling inflation, it can promote financial instability. Against the background of the tremendous increase in capital mobility and financial globalization, which produces more rapid transmission of crises or shocks across countries or continents, emerging countries with a large amount of foreign-denominated debt in particular have experienced serious financial and currency crises. ${ }^{40}$ It is now widely believed that a global move toward greater exchange rate flexibility, on the one hand, or toward fixed exchange rates, on the other, would have diminished many of the problems that the international financial system has suffered in recent years, although it is possible, or even likely, that no exchange-rate regime would have prevented the recent crises in the emerging-market economies. ${ }^{41}$ In particular for most emerging market

\footnotetext{
${ }^{40}$ A main element of the crises was the weakness of the bank supervisory process which often is prevalent in emerging markets and transitional countries; see Alba et al. (1998), Furman/Stiglitz (1998), and Berg (1999).

${ }^{41}$ See Frankel (1999), Mussa et al. (2000), Wagner (2000d).
} 
economies, floating exchange rate regimes appear to be the increasingly relevant choice. ${ }^{42}$ The reason is that these countries are increasingly integrated with modern financial markets; ${ }^{43}$ and the policy requirements for maintaining a pegged exchange rate can be very demanding in circumstances of high international capital mobility (Mussa et al. (2000)). ${ }^{44}$

Beyond the relatively few 'emerging markets', ${ }^{45}$ however, there are the majority of developing and transitional economies. These economies do not have highly sophisticated domestic financial systems. In addition, they are not deeply integrated into the world capital markets, and they often still maintain rather extensive controls on capital account transactions. For these economies, pegged exchange rate regimes (in whatever form) can be viable for extended periods, if monetary and fiscal policy can maintain reasonable discipline. Nonetheless, when these economies become more developed and more financially sophisticated, and when they are more integrated into global financial markets, they also may be forced to consider regimes of greater exchange rate flexibility. ${ }^{46}$ The alternative is to adopt very hard pegs (dollarization and monetary union) ${ }^{47}$ However, even such corner solutions which, as mentioned, are not necessarily the best solution for all economies ${ }^{48}$ - would have to be supplemented by further institutional measures or

\footnotetext{
${ }^{42}$ See Eichengreen et al. (1999).

${ }^{43}$ Among countries with open capital accounts, soft pegs have proved to be crisis-prone and not viable over long periods. The major part of the explanation for this is the impossible trinity of a fixed exchange rate, capital mobility, and a monetary policy dedicated to domestic goals.

${ }^{44}$ This does not exclude that, for certain emerging market economies, pegged exchange rate regimes can be workable, despite substantial involvement with global financial markets. In particular countries with a past history of poor inflation performance may find that only with a very strong commitment mechanism to an exchange rate peg (as in a currency board or full dollarization) can inflation be controlled.

${ }^{45}$ Fischer (2001) listed 33 emerging market economies out of the then 182 members of the IMF at the end of 1999.

${ }^{46}$ See Wagner (1998, 2000e), Mussa et al. (2000).

${ }^{47}$ Fischer (2001) states: "It is reasonable to believe, as EMU [European Monetary Union] expands, and as other economies reconsider the costs and benefits of maintaining a national currency ... that more countries will adopt very hard pegs, and that there will in the future be fewer national currencies" (p. 10).

${ }^{48}$ There are arguments in the literature that corner solutions are no real alternatives since optimal policy implies 'dirty floating' (Chang and Velasco (2000)). In particular, 'dirty floating' is contended to be optimal when inflation targeting is chosen as the basis for its monetary policy (ibid). When exchange rate flexibility increases, it is important for a country to determine the basis for its monetary policy. The record of inflation targeting is often regarded to be a good one in this regard, see Bernanke et al. (1998), Fischer (2001); see, however, Masson et al. (1997), and Wagner (1999b). The fact that obviously in practice there always (or mostly) is dirty floating (see Calvo and Reinhart (2000) for an explanation), however, can be seen as the real danger so that a corner solution such as dollarization just therefore may be the better alternative, see Reinhart (2000).
} 
innovations to minimize risks of future currency and financial market crises (Fischer (1999)). Here we can differentiate between measures which countries can take at unilateral or bilateral levels, at plurilateral or regional levels, and at the multilateral or global level (Wagner (2000d)).

The conclusion is that a pegged exchange rate regime, although it may be a successful strategy for controlling inflation, may increase financial instability, in particular in emerging market economies. To minimize this danger, a healthy banking system has to be installed. This, in addition to a decrease in short-term debt denominated in foreign currencies as well as an increase in holdings of international reserves may insulate countries from financial crises.

\section{Interpretation}

On the basis of the above analyses and interpretations, one may come to the conclusion that globalization tends to decrease (suppress) inflation (pressures). However, the model of a delay of reform has shown that there is no coercive pressure, however a tendency towards a greater of lesser decrease in inflation in the medium term exists. This conclusion can be reaffirmed by considering that not only inflation, but also high fiscal burdens (direct tax load and indebtedness) have to be considered as typical negatively rated locational factors in the locational competition between countries or governments (UNCTAD (1999)).

On the one hand, this leads to what is called 'fiscal discipline' (see Wildasin (2000), Citrin and Fischer (2000)). Effective locational competition in a globalized economy involves fiscal discipline where governments tend to compete with other countries or economies in reducing their expenditures (hence their budget deficits and their indebtedness) and taxes to levels or ratios which are similar to or even below those of competing countries or economies. ${ }^{49}$ This appears to make it easier for monetary policy to prevent inflation, which can be regarded to be its central task.

\footnotetext{
${ }^{49}$ One should add, however, that this competition process is likely to be effective only among countries or regions of similar development stages (Baldwin and Krugman (2000)) so that there may be multiple equilibria. This implies that not all countries or regions in competition must head towards the same rates of taxes, debts, or inflation, since there always remain structural differences between these countries or regions. This is also the reason that the optimal degrees of structural deregulation are different in different countries. Nonetheless, even competition among similarly developed countries or regions leads to a pressure towards lowering 'locational bads' such as tax loads, indebtedness, etc.
} 
Therefore, one may come to the conclusion that, as a result of globalization, fiscal policy tends to become more disciplined and inflation will go down, so that the 'new paradigm'-view of inflationless growth in the 'New Economy' appears to be based on sound fundamentals.

On the other hand, however, there are some caveats with respect to this view which may be relevant, in particular for developing and transition economies. The main caveat is based on the following:

The described globalization-driven pressure on governments to reduce taxes may increase the optimal share of seigniorage in financing governmental expenditures. Why? We have mentioned the incentive to reduce government debt and expenditure (that may end up in a 'race to the bottom') as an effect of locational competition. There is, however, a trade-off: not only taxes, expenditures and debt are important locational factors in the competition for direct international capital investments; another important locational factor is the infrastructure, which includes physical goods such as roads, ports or telecommunications, institutional aspects such as property rights, contract enforcement and, last but not least, educational goods (threshold levels of skills are needed to attract inward investment). ${ }^{50}$

Governments, however, can only finance this infrastructure by increasing expenditure, if there is no politically accepted way of shrinking other expenditures. This can only be done by raising taxes, increasing debt, or by expanding seigniorage which, however, tends to produce inflation. The government is therefore obviously captured in a trap or trade-off situation. All three choices of financing this infrastructure are undesirable on the basis of locational competition. However, by considering the trade-off situation, none of these choices can be rated as bad per se since, for example, an increase in taxes does not deter investment if these taxes finance public intermediate inputs that are valued by firms and investors. A policy of inflation surprises could well be regarded by a government as the least costly alternative (in political terms) to finance the desired infrastructure. This is particularly the case in developing or transitional countries (Wagner (1997)). Hence governments there would have to raise the inflation target, and the inflation bias would rise if the tax revenue becomes lower and lower and there are necessary or desired higher expenditures for public goods (such as legal security, education etc., which, as mentioned, are also important locational factors in the competition for human capital and direct foreign investments).

\footnotetext{
${ }^{50}$ See Section II.A.
} 
30 Persisting Effect of Globalization: Increase in Competition

This trade-off dilemma can only be overcome or mitigated if a government succeeds in increasing economic growth. An increase in economic growth would, as a by-product, also increase tax revenue with which the increased expenditures on the desired infrastructure could be financed if government does not want to increase debt. This is exactly the vision of a 'New Economy'. ${ }^{51}$ An example of this is the United States in the 1990s. The optimistic view on globalization expects, as by-products, increasing productivity (growth) and a New Economy. ${ }^{52}$ Whether this is realized, however, is dependent upon certain microeconomic and institutional adjustments or reforms which not every country is capable of easily implementing because of politico-economic constraints. ${ }^{53}$

\section{Policy Implications}

We have analyzed several arguments and models which support the view that globalization tends to reduce the inflation (bias). Therefore, globalization appears to improve the conditions for and thereby ease price stability policy of central banks. Nevertheless, alertness is still needed because the conclusion that globalization reduces inflation is not generally true. We have seen (in model approach I) that there is even the possibility that globalization, under certain circumstances, produces the opposite result. This is based on costs of reforms. Moreover, as argued in the foregoing section, there are trade-offs between different locational goods which a country tries to attain. Therefore, there is no reason for central banks to conduct the price stability task under globalization more laxly (or even for the government to reduce the degree of central bank independence). It is quite the reverse: increased locational competition forces the central bank to concentrate on and conduct price stability policy even more carefully in order to attract or avoid a drain of mobile capital. Furthermore, it has to be considered that, as globalization goes hand in hand with or is based on IT innovations, the uncertainty which surrounds monetary policy increases, as will be examined in the next chapter. This increase in uncertainty tends to make the task of price stability policy transitorily even more difficult.

\footnotetext{
${ }^{51}$ More details of this will be found in the following chapters.

${ }^{52}$ As argued above, the two main components of a New Economy can be seen in globalization and productivity-increasing IT innovations.

${ }^{53}$ See also Section IV. Another big hope, which is often expressed, is that globalization enforces structural adjustments on the side of labor unions which may create disciplining inflationreducing effects.
} 
Nevertheless, when globalization is believed to suppress inflation pressures, it may be tempting for specific social interest groups to pressure the central bank to reduce its efforts in the fight against inflation in favor of the fight against (for example) unemployment or economic recession. As examined in this chapter, this may be justified by the argument that fiscal policy may be bound by the disciplinary effects of the locational competition, which is intensified by globalization. This might mean that governments are not able (or are limited in their ability) to use fiscal policy (particularly an increase in government expenditure which would raise government debt or taxes) for expansionary stabilization policy actions. Monetary policy will then be made more responsible for economic stabilization than it has been before. This means that monetary policy will be expected to fight economic recessions, mainly by lowering short-term interest rates.

If globalization tends to decrease inflation, it consequently will also diminish nominal short-term interest rates, perhaps to very low levels. In a situation of very low inflation and very low nominal short-term interest rates, however, monetary policy may not be effective in its attempts to stimulate aggregate demand during a recession, because of the zero bound on nominal interest rates. This zero bound is a consequence of the fact that nobody will be ready to lend money at negative nominal interest if cash is costless to hold over time. In particular, the nominal inter-bank interest rate will not fall below zero since electronic bank reserves can be stored at central banks for free. ${ }^{54}$ This could increase the danger that a cyclical downturn could push an economy into deflation and stagnation. ${ }^{55}$ Deflationary pressure may rise in a low inflation environment due to difficulties of real wage adjustment and the adverse effects of debt deflation and credit crunch. ${ }^{56}$

Over and above this, it may be argued that central banks can be fooled by their own credibility for low inflation (based, for example, on the increase in

\footnotetext{
${ }^{54}$ One could, however, think of some institutional solutions by which the central bank could try to overcome the zero bound problem. For example, a central bank could establish a carry tax on electronic bank reserves. Or a central bank could undertake aggressive open market purchases, i.e. buy relatively illiquid assets, such as long-term bonds, and thus increase broad liquidity. However, in order to be effective, the latter may require very large monetary injections. Moreover, it may only be effective if the public believes that the central bank will do whatever it takes and that the monetary stimulus will not be withdrawn before the recession is over. To help assure the credibility of such a monetary policy, fiscal policy could indemnify the central bank against capital losses. See Goodfriend (2000).

${ }^{55}$ An example of this type of scenario can be seen in the recent problems in the Japanese economy. See Goodfriend (2000).

${ }^{56}$ See Shiratsuka (2000).
} 
32 Persisting Effect of Globalization: Increase in Competition

competition induced by globalization described above) into being insufficiently preemptive in a business expansion (Goodfriend (2000)). Central banks may be inclined, in the belief of the inflation-suppressing power of this competition, to delay monetary tightening when the economy moves beyond a presumed level of non-inflationary potential output. If, however, the economy continued to run above potential, the credibility for stable prices would, at some point, self-destruct. This would create a jump in inflation, so that the central bank would then be forced to react with tighter monetary policy. It would produce, what is often called a 'hard landing' for the economy. The outbreak of inflation would destroy a kind of implicit reputational equilibrium in which price and wage setters kept their part of an implicit bargain, which means that they did not inflate as long as the central bank (or the globalization-driven competition) was expected to support its commitment to price stability. An obvious conclusion, which is drawn, is that a central bank should be sufficiently preemptive in a boom (see Goodfriend (2000)). 


\section{Transitory Effect of Globalization: Increase in Uncertainty}

\section{A. Structural Changes and Uncertainty}

In Section II, we analyzed various models which showed that globalization tends to decrease inflation, though in most cases only with a certain time lag. Without any time lag, however, the manifold structural changes associated with the globalization process increase the uncertainty which surrounds monetary policy. ${ }^{57}$ In particular, the IT innovations, that function as the technological basis of the globalization process ${ }^{58}$ induce this effect. This effect of an increase in uncertainty, which is likely to be transitory, will be analyzed by considering a central bank, whose strategy can be expressed by a Taylor rule:

$$
r_{t}=r^{*}+\alpha\left(\pi_{t}-\pi^{*}\right)+\beta\left(y_{t}-y^{*}\right), \alpha, \beta>0,
$$

where $r_{t}$ is the short-term real interest rate; $r^{*}$ is the long-term equilibrium real interest rate; $\pi^{*}$ is the target inflation rate; $\pi_{\mathrm{t}}$ is the current inflation rate; $y^{*}$ is the potential output rate; and $y_{t}$ is the current output rate. " $\alpha$ " is the weight ascribed to the inflation gap and " $\beta$ " is the weight ascribed to the output gap.

The 'Taylor rule' - which can be derived by combining a macro model, consisting of a Phillips curve and an IS curve, with a policy target (and a loss function) - represents the (optimal) reaction function or policy rule followed by the policymaker under a certain monetary policy target regime. The model may either be backward-looking (as in Ball $(1997,1999)$ ) or forwardlooking $^{59}$ (as in McCallum (1997b)). The parameters $\alpha$ and $\beta$ (when they are not simply regarded as given, as in Taylor (1993)) reflect the weights of the variability of output and inflation in the loss function of the central bank and structural parameters of the economy.

\footnotetext{
${ }^{57}$ See Issing (1999). Issing refers to "Knightian" uncertainty that confronts central bankers, referring to the often-cited difference between risk and (true) uncertainty (Knight (1921)).

${ }^{58}$ As emphasized in the introduction, the present globalization process is hardly imaginable without the driving force of the IT innovations. These IT innovations are the technological basis or driving force of the globalization process insofar as they drastically reduce the transaction costs of goods and factor mobility.

${ }^{59} \mathrm{~A}$ forward-looking model includes expectations of future values of endogenous variables.
} 
34 Transitory Effect of Globalization: Increase in Uncertainty

We shall argue in this chapter that the structural (technological and political) changes which substantiate or symbolize the globalization process increase the uncertainty about the output gap $\left(y_{t}-y^{*}\right)$ and the inflation gap $\left(\pi_{\mathrm{t}}-\pi^{*}\right)$, as well as the uncertainty about the monetary transmission, mechanism and hence about the weights $(\alpha, \beta)$.

As we are concerned with the impacts of globalization, one may think of extending the basic Taylor rule by the inclusion of exchange rate movements (see Ball (2000)). To improve the macroeconomic performance, the Taylor rule could take account of excessive exchange rate fluctuations:

$$
r_{t}=r^{*}+\alpha^{\prime}\left(\pi_{t}-\pi^{*}\right)+\beta^{\prime}\left(y_{t}-y^{*}\right)+\gamma\left(e_{t}-e^{*}\right), \alpha^{\prime}, \beta^{\prime}, \gamma>0,
$$

where $e$ denotes the short-term nominal exchange rate and $e^{*}$ the long-term equilibrium nominal exchange rate.

At first sight, this extension appears to be reasonable (at least for small economies) since excessive exchange rate fluctuations involve costs for the society which are reflected in larger fluctuations in output and inflation. At second sight, however, doubts may be raised about the appropriateness of including the exchange rate into the Taylor rule. A key counter-argument is that the basic Taylor rule already implies that the interest rate is raised during inflationary exchange-rate-led booms and is decreased during deflationary exchange-rate-induced busts. Therefore, it may be regarded as unnecessary to explicitly include the exchange rate into the Taylor rule. Another potential counter-argument against including the exchange rate into the Taylor rule is the following: exchange rates are just too volatile, and reacting to exchange rate misalignments may result in excessive interest rate fluctuations and therefore be destabilizing. Furthermore, it is nearly impossible to know for sure whether a given change in exchange rates results from fundamental factors, non-fundamental factors, or both.

The Taylor rule is attractive because it responds directly to deviations from central banks' objectives, in particular from the U.S. Federal Reserve's objectives which are price stability and equilibrium utilization rate (Meyer (2000)). However, implementing this rule requires knowledge of, among other things, the output gap and the equilibrium real interest rate.

These variables are affected by structural change in the context of globalization. As a result, there has been increased focus on how Taylor-type rules should be adjusted in light of the uncertainties associated with structural changes that are a by-product of the globalization process. 
The objective of this chapter is to make clear that, transitorily, the structural changes associated with the globalization process increase the uncertainty about the current state of the economy - here output and inflation gaps - (see Section B) and about how the policy instruments affect inflation and economic activity - the monetary transmission mechanism (Section C). ${ }^{60} \mathrm{In}$ particular, we examine the effects of the IT innovations behind globalization.

\section{B. Increase in Uncertainty About the Output and Inflation Gaps}

Here, two aspects in particular are highlighted. On the one hand, the structural changes associated with the globalization process increase the uncertainty with respect to productivity growth (and hence potential output), and on the other hand, decrease the information content of the price level. Both increase the uncertainty with respect to the output gap and the inflation gap.

\section{Uncertainty about the output gap}

\section{Implications of the uncertainty about productivity growth}

As already briefly mentioned, the IT innovations and globalization can be regarded as the two main components of the so-called 'New Economy' phenomenon. This 'New Economy' resembles the pattern of economic activity in the USA since 1993: there technical progress or innovations (within a relatively deregulated economy) have led to higher productivity and economic growth without significant inflation, and to lower fluctuations in business cycles.

The questions now arise whether these changes will continue; in particular, whether productivity growth will continue at such a high rate; and whether this process will spread to other countries or continents? This is important for a monetary authority to know in order to assess whether it should now react differently to a booming economy, as the increase in productivity creates the possibility of high economic growth without inflation or with low inflation. ${ }^{61}$

The future development of productivity growth, and (as its basis) innovations, however, is uncertain and hard to foresee because of natural reasons. Forecasting innovations largely means, forecasting the future which in itself is

\footnotetext{
${ }^{60}$ In this chapter we can build upon a body of research recently undertaken on at least some aspects of our topic, whereas very little literature exists on the topics considered in Section II.

${ }^{61}$ In this paper, however, the inflation-suppressing effect has, up to now, been derived without referring to an increase in productivity growth.
} 
36 Transitory Effect of Globalization: Increase in Uncertainty

uncertain. Therefore there are no clear answers to the question of whether productivity growth will continue at a high rate for example in the USA. It may be that, over the next few years, the recent higher rates of productivity growth will persist as, for example, businesses adapt to new technologies such as the internet. From a longer-term perspective, however, it may be that the USA is experiencing a shift in the level of productivity rather than in its growth rate. Hence, policymakers face unavoidable uncertainty concerning both short- and longer-term productivity prospects. Whether this is a mere level or a growth rate effect, depends upon whether new technologies such as the internet represent only process innovations or also lead to (continuing) product innovations. Mere process innovations tend to lead to labor reductions whereas product innovations create new activity or production fields.

One should, however, consider that it is not (alone) a technical matter but also and mainly an institutional matter whether the increase in productivity and consequently in potential output endures. The reason is that technical progress can only be made productive if it is accompanied by adequate or necessary institutional measures or changes. And these changes can be influenced or produced by good will and good policy.

Any (uncertain) changes in the level or growth rate of productivity per se (to an uncertain extent) also change the output gap - actual output minus potential output - if only because they change the supply and the output potential or target. ${ }^{62,63}$

${ }^{62}$ Vickers (2000) argues that the actual or current output rate may also change. The reason, as he argues, is that supply shocks are unexpected changes in supply capacity. If the internet, say, improves productivity, that will arrive as a shock to future productive potential. But once an improvement to the supply side has come to be anticipated, demand and hence actual output too may be boosted. This is thought to lead to additional uncertainty with respect to the effects of unexpected supply shocks on the output gap.

${ }^{63}$ There is a well-developed literature on the effect of uncertainty on policy. Recently, several authors have investigated the implications of incomplete information about potential output for the conduct and design of monetary policy by studying this issue more formally in quantitative models of optimal monetary policy (Orphanides (1998), Rudebusch (1999), Ehrmann and Smets (2000), Swanson (2000), Svensson and Woodford (2000)). In some of these studies, certainty equivalence continues to hold, even with noisy observations. That is, incomplete information about potential output does not significantly change results with respect to optimal monetary policy derived in models with perfect information, as long as the central bank uses its best estimates of the state of the economy and has the true model of the economy at its disposal. However, one may question the practical significance of certainty equivalence, which requires that policymakers know the true model, use an optimal rule, and update their optimal estimate of the NAIRU based on the true model (Meyer (2000)). These assumptions or requirements put a strong restriction on the results. Another restriction is that these results, as with most mainstream results in the theory of optimal monetary policy, very much depend on the linear-quadratic framework used in their approach and tend to break down when non-linearities or model uncertainty are considered. 


\section{Implications of the uncertainty about the information content of the price level}

The vision of a New Economy, built upon ongoing IT innovations and globalization (which creates larger markets), implies the expectation of rising stock values. This may, as recent experience indicates, result in asset price bubbles. (A bubble here is defined as a process that, for a while, drives an asset price, in an explosive way, away from its fundamental level.) This, however, tends to lower the information content of the price level and hence is of significance for monetary policy (see also and in more detail in the following section). ${ }^{64}$

Recently, there has been much debate about whether monetary policy makers should attempt to restrain or 'prick' perceived asset price bubbles. A key question in this context is whether monetary policy should, as part of its pursuit of inflation and output gap stability, react explicitly to deviations of asset prices from their steady-state or fundamental levels (see Kent and Lowe (1997), Bernanke and Gertler (1999), Cogley (1999), Cecchetti et al. (2000)). ${ }^{65}$

In consistency with the just mentioned bubble argument, one can argue that this New Economy (the combination of IT innovations and globalization) may lead to an increase in (the volatility of) asset prices. Asset prices, however, as is well known, matter for spending and pricing decisions in goods markets. ${ }^{66}$ This means, even if the central bank assumes that the increase in

\footnotetext{
${ }^{64}$ In principal, one can differentiate between two questions which are relevant for monetary policy in this context: first, should financial market stability be included in the central bank's target function? Today this is being increasingly affirmed. Second, even if the first question is not affirmed, the question remains of how should central banks react to asset price movements. Here we only deal with the second question.

${ }^{65}$ Much of this debate has been motivated by the experiences from the U.S. stock market during the mid and late 1990s. Not only asset prices but also exchange rates are apparently hit by bubbles. So it may be claimed that the appreciation of the U.S. dollar from 1980 to 1985 was excessive compared to underlying fundamentals (Okina (1984), and Evans (1986)). In the following, we refer mainly to asset prices. However, the arguments refer also to exchange rates.

${ }^{66}$ One mechanism often cited is that changes in asset prices affect consumption spending via their effects on household wealth. Empirical studies (Ludvigson and Steindel (1999), Parker (2000)) have, however, not always found a strong or reliable connection. Another much-cited mechanism refers to the so-called "balance sheet channel" (Bernanke and Gertler (1995)). This view maintains that credit markets are not frictionless, and hence cash flows and the condition of balance sheets are important determinants of agents' ability to borrow and lend. For instance, firms and households may use assets they hold as collateral when borrowing, in order to improve information and incentive problems that would otherwise interfere with credit extension. An increase in asset values, for example, would improve potential borrowers' access to credit. This primarily operates on spending and aggregate demand in the short term, although in the longer run it may also affect aggregate supply by facilitating capital formation and increasing working capital. There may also be feedback to asset prices, as increasing spending and income, together with asset purchases, lead to further increases in asset values.
} 
38 Transitory Effect of Globalization: Increase in Uncertainty

potential output is going to continue as a consequence of the New Economy, ${ }^{67}$ this does not automatically mean that the output gap (which is one of the measures we sometimes identify with 'excess demand') would be reduced. ${ }^{68}$ Not only would potential output (or supply) and therefore the output target be increased, but demand may also go up, possibly by even more than supply. This is because of the increase in the volatility of asset prices emphasized above which may accompany extended periods of upsurges in asset prices.

An increase in asset prices may create excess demand effects insofar as assets (or wealth) are used as banking collateral. Progress in information technologies, for example, may lead to speculative appreciation of firms located in the also-so-called New Economy. This can produce speculative bubbles and higher investments and output.

Again this means that not only potential output or output capacity but also actual output may increase. Hence it is uncertain how the output gap develops as a consequence of a New Economy. For an extended period, demand may even increase by more than supply, as, for example, stated by Alan Greenspan in his Humphrey-Hawkins testimony to Congress on February 17, 2000: "the pickup in productivity tends to create even greater increases in aggregate demand than in potential aggregate supply." ${ }^{\prime 9}$

For the central bank, however, the question then arises of how it should react to the prospective, uncertain changes in the output gap. ${ }^{70}$

\section{Uncertainty about the inflation gap}

\section{Implications of the uncertainty about productivity growth}

In a range of simple macroeconomic models, the dynamics of inflation depend, among other things, on the output gap (see McCallum and Nelson

\footnotetext{
${ }^{67}$ Central banks, however, do not know exactly whether what they see is really the phenomenon of a continuing structural change named the New Economy or just a longer-thanusual ongoing cyclical upswing. This upswing could have been based on firms having met an increase in demand by intensifying resource use beyond normal, sustainable levels thus producing a kind of cyclical pickup in productivity growth which could slow down after a while.

${ }^{68}$ See Vickers (2000) for a more detailed analysis of the argument developed in this section.

${ }^{69}$ The increase in demand may not only be based on an increase in asset prices (as described above) but could also be based or supplemented by other mechanisms (Vickers (2000)).

${ }^{70}$ This includes the question of whether it should also change its monetary strategy, perhaps go over to a nominal income strategy (see Jensen (1999), McCallum and Nelson (2000)). There are, however, good arguments for why such changes should only be made if the central bank thinks that changes are enduring since activist discretionary policy changes are not regarded to be an optimal way of conducting monetary policy (see Solans (2000)). On the policy implications of uncertainty see section D. below for more details.
} 
(1997), Clarida et al. (1999), and Woodford (1999a)). And in practice, to achieve their price stability objectives, many central banks use the output gap as an indicator of future price pressures. Unfortunately, however, potential output and hence the output gap is unobserved and, as with estimates of other unobserved variables such as the NAIRU or the equilibrium real interest rate, there is no obvious way in which it can be defined and estimated.

A positive output gap tends to create rising inflation - as firms reach full capacity utilization - and an increasing output gap tends to accompany accelerating inflation, and conversely for negative and falling output gaps.

This kind of framework, which can be built up from microeconomic foundations, offers a simplified but coherent account of how supply side developments can affect the paths of nominal variables. A positive supply shock, such as unexpectedly higher productivity growth, here reduces the output gap and thus lowers the path of inflation for a given path of nominal interest rates.

At first sight, it may seem certain that the IT innovations, which are the technological basis of today's globalization process, by producing a positive productivity or supply shock, will moderate inflation. Moreover, it may appear likely that they also reduce the NAIRU via effects on product market competition and by improving the efficiency of matching people to jobs in the labor market (Wadhwani (2000)).

However, as noted earlier, supply shocks are unexpected changes in supply capacity, and once an improvement to the supply side is anticipated, demand, and hence actual output too, may be raised. Thus the effects of unexpected supply shocks, such as the internet, on the output gap are uncertain and so, therefore, are the effects on the inflation gap.

Implications of the uncertainty about the information content of the price level

As described above, a New Economy may imply the expectation of rising (volatility of) asset prices. Asset prices, however, are regarded to be a relevant variable for forecasting inflation insofar as they matter for spending and pricing decisions in goods markets. A question raised recently in this context is whether this implies that inflation-targeting central banks should respond to asset prices or exchange rates specifically.

A number of economists, including recently Bernanke and Gertler (1999) and Vickers (1999), have argued that it is sufficient if policy makers respond to 
40 Transitory Effect of Globalization: Increase in Uncertainty

expected inflation as this would fully capture an adequate response to asset prices. ${ }^{71}$ The main argument is that it is nearly impossible to know for sure whether a given change in asset values results from fundamental factors, nonfundamental factors, or both. Inflation targeting would imply that interest rates tend to rise during inflationary asset price booms and fall during deflationary asset price busts. Hence this approach will allegedly reduce the potential for financial panics. ${ }^{72}$

This obviously is the predominant view today, not only among academics but also among central bankers: it states that central banks should set interest rates in response to actual or forecast inflation, and possibly also in response to the output gap, but should not react systematically to asset price (or exchange rate) developments. The reasoning behind this position is, as noted earlier, that asset prices (including exchange rates) are too volatile and that reacting to asset price misalignments may be destabilizing.

However, there are also significant counter-arguments to this position. Cecchetti et al. (2000), for example, maintain that there is a gain in macroeconomic performance if policy makers respond separately to asset prices in a monetary policy rule over and above the expected inflation term. Cecchetti et al. argue that when bubbles burst, there can be significant economic damage. Therefore it is necessary to try to limit the emergence of asset price misalignments. This should be done by leaning against emerging asset price alignments, even if this causes a short-term deviation from the inflation goal. A policy rule which explicitly includes asset prices ${ }^{73}$ would limit moral hazard problems because monetary policy would react

\footnotetext{
${ }^{71}$ A main counter-argument, however, is that there are multiple inflation prognoses and expectations if there is a bubble.

${ }^{72}$ Bernanke and Gertler (1999) maintain that central banks should view price stability and financial stability (of which one important dimension is increased volatility in asset prices) as highly complementary and mutually consistent objectives, to be pursued within a unified policy framework, and they think the best framework is a regime of flexible inflation targeting. The key-advantage of such a regime is that it induces policymakers to automatically adjust interest rates in a stabilizing direction in the face of asset-price instability: because asset price increases stimulate aggregate demand and asset price declines dampen it, the strong focus of inflation-targeting central banks on stabilizing demand will result in "leaning against the wind", raising interest rates when asset prices rise and reducing them when they fall. The logic of inflation targeting would imply that central banks should ignore movements in stock prices which apparently do not generate inflationary or deflationary pressures.

${ }^{73}$ As we have shown in the introduction, the simple Taylor rule could easily be augmented to include a link between interest rates and exchange rate or asset price alignments. This would have implied higher short-term interest rates in situations over recent years, at least in the United States.
} 
symmetrically to asset price movements. When price changes originate in asset markets, the central bank may need to react in order to counter the effects on inflation. This could arise with a change in the equity risk premium (the difference between the return that investors require on equities relative to bonds). Recent surveys indicate that U.S. equity holders used to expect annual returns of 10-12 percent which was significantly higher than implied by the equity risk premium (see Cecchetti et al. (2000)). This suggested aboveaverage risk to holding U.S. equities.

All the studies mentioned here, however, agree that it is appropriate to respond to asset prices (including exchange rates) in some way; however, the question is open whether expected inflation serves as a sufficient statistic for the effects of asset prices on welfare, so that, given expected inflation, there is no role for asset prices in monetary authorities' reaction functions.

\section{Increase in the Uncertainty About the Transmission Mechanism}

\section{Increase in the use of e-money}

We have defined globalization as a process of growing economic interdependence which results partly from the rapid and widespread diffusion of new technologies. One of these new technologies is e-money. The increasing use of e-money, however, clouds the significance of conventional monetary aggregates. When the significance of conventional monetary aggregates weakens, the central bank becomes more uncertain about the monetary transmission mechanism, i.e. about how the monetary instruments affect inflation and economic activity, in terms of both size and timing.

Previous financial innovations, such as mutual funds that allow checks to be written against deposits, have already impaired the central banks' ability to control monetary aggregates such as M2. Monetary policy's power may weaken further as stored-value cards and online cash substitutes catch on, creating 'electronic money' beyond the direct control of central banks. In addition, because more transactions will bypass banks, the central banks' ability to set the required reserve ratio may have less effect on the economy. The question which has recently been raised and has now attracted widespread attention is whether technological innovations will hamper the central banks' ability to carry out operations that reliably affect economic activity in the usual sense of real output and/or price inflation (Friedman $(1999,2000))$. The threat to monetary policy from the electronic revolution in banking is seen in "...the possibility of a 'decoupling' of the operations of the 
central bank from the markets in which financial claims are created and transacted in ways that, at some operative margin, affect the decisions of households and firms on such matters as how much to spend (and on what), how much (and what) to produce, and what to pay for ordinary goods and services" (Friedman (2000, p. 2); emphasis in the original). ${ }^{74}$ Coupling, at the margin, of operations by the central bank and the decisions of households and firms, however, is crucial to monetary influence over output and/or prices, as all standard theories of how monetary policy works maintain. Since this is an argument referring to coupling at the margin, the threat of decoupling is not dependent upon the extreme assumption sometimes made that, in the future, possibly nobody will use currency for ordinary economic transactions any more. $^{75}$

A main counter-argument to the hypothesis in this discussion is that central banks can always anchor the entire structure of interest rates by being willing to lend to the private economy (via banks) in potentially infinite volume. ${ }^{76}$ This procedure, however, may involve central banks in potentially very large transactions which may produce instrument instability. This potential problem may be weakened by the fact that apparently modern financial markets react more sensitively to possible changes in monetary policy (Issing (1996)). Nevertheless, the central question remains of how a central bank can anchor the structure of interest rates by means of only very small transactions compared to the size of its economy or its financial markets. One possible answer is given by Goodhart (2000, p. 27): "Because the other players in the

\footnotetext{
${ }^{74}$ In other words, the issue is "whether the expansion or contraction of that quantity, or the increase or decrease of the exchange rate on central bank liabilities against some other asset, would continue to be connected to the expansion or contraction of economic activity and to the broader constellation of interest rates and asset values that matter for this purpose" (Friedman (2000, p. 9)).

${ }^{75}$ This is not actually likely since, if regarded to be a problem, an easy solution for this would be to require all government tax payments to be made in central bank liabilities. Even without this obligation, central bank money (currency) will not vanish as it has the advantage, as against emoney, of absolute anonymity, which is important for many people when carrying out cash payments. Moreover, currency is and will be the only riskless asset which implies the ultimate source of confidence.

76 See Woodford (2000a). Woodford argues that central banks can successfully steer economies even in a world where cash is disappearing. The reason is that a central bank can set monetary policy by controlling interest rates (by lending/borrowing e-money above/below the current market interest rate), rather than by altering the currency supply. In other words, reserve requirements are not an essential part of monetary policy. This, however, does not exactly hit the point that some economists, such as Friedman (2000), have in mind when they claim that electronic advances in banking practices may present complications for central banks, perhaps even to the point of threatening the efficacy of monetary policy influence over inflation and economic activity. For this, see above.
} 
money market, whether banks or not, know that the Central Bank has the power of the government behind it, it is actually unlikely that the Central Bank will normally have to undertake a large volume of open market operations to get the market to adjust interest rates in line with its wishes. Open mouth policy will normally suffice". But, as Friedman (2000, p. 16) emphasizes, "... what if the market loses its presumption that the central bank could, or would, be able to do the job if the market did not simply act on its signals? With nothing to back up the central bank's expressions of intent, I suspect that in time the market would cease to do the central bank's work for it. This prospect is ultimately what the threat posed to monetary policy by the electronic revolution is all about". ${ }^{77}$

\section{Effect on inflation}

In the following, we derive the effects of an increase in uncertainty about the monetary transmission mechanism on inflation by referring to the basic model presented in chapter II. Since it was noted by Brainard (1967), uncertainties about the transmission mechanism are registered not only with the help of additive shocks, but above all by taking into account uncertainty about the multipliers. Therefore we replace equation (3) in the basic model by the following modified version: ${ }^{78}$

$$
\pi=\eta \cdot m+v \quad \text { with } E(\eta)=1, \sigma_{\eta}^{2}=\text { const. }, \sigma_{v \eta}=\sigma_{\varepsilon \eta}=\sigma_{v \varepsilon}=0
$$

For inflation with an optimal (active) policy rule we find the solution:

$$
\pi_{O}=\frac{\eta \pi^{*}}{1+(1+b) \sigma_{\eta}^{2}}+\frac{\eta b \varepsilon+(1+b)\left(1+\sigma_{\eta}^{2}-\eta\right) v}{(1+b)\left(1+\sigma_{\eta}^{2}\right)}
$$

For the derivation see Appendix II.

\footnotetext{
${ }^{77} \mathrm{I}$ do not want to go further into this debate. I just wanted to make clear that the assumption, that the financial innovations which enhance the globalization process will increase the uncertainty about the monetary transmission mechanism, is not void or implausible (see also Taylor (1998) on this point). What can be said with certainty is that an increase in the use of e-money will, in addition to reducing seigniorage incomes, reduce the stability of money demand and worsen the indicator quality of conventional monetary aggregates.

${ }^{78}$ This model variation is also used by Letterie and Lippi (1999). However, these authors are primarily occupied with the welfare effects of instrument uncertainty with discretionary monetary policy. In contrast to this, we shall explicitly compare the rule-bound solution with the discretionary solution in the following. Moreover, contrary to Letterie and Lippi (1999), the existence of supply shocks is taken into account and it is also assumed that the socially desired inflation rate $\left(\pi^{*}\right)$ is not necessarily zero.
} 
With discretionary policy it follows for inflation:

$$
\pi_{D}=\pi_{O}+\frac{\eta b\left(y^{*}-y_{n}\right)}{1+(1+b) \sigma_{\eta}^{2}}
$$

Again, see Appendix II for the derivation.

From this, we can derive ${ }^{79}$ that, on the one hand, an increase in multiplier uncertainty (i.e., an increase in $\sigma_{\eta}^{2}$ ) leads to a reduction in the inflation bias. The following applies:

$$
E\left(\pi_{D}\right)-E\left(\pi_{O}\right)=\frac{b\left(y^{*}-y_{n}\right)}{1+(1+b) \sigma_{\eta}^{2}}>0
$$

On the other hand, we find, that, if a ( $n$ optimal) policy rule ${ }^{80}$ is pursued, inflation, on average, falls below the socially desired rate of inflation, if $\pi^{*}>0$. The following applies:

$$
E\left(\pi_{O}\right)=\frac{\pi^{*}}{1+(1+b) \sigma_{\eta}^{2}}<\pi^{*}, \text { with } \frac{d\left(E\left(\pi_{O}\right)\right)}{d\left(\sigma_{\eta}^{2}\right)}<0, \text { when } \pi^{*}>0
$$

This undercutting must not be interpreted in the sense of an incentive to depart from the rule solution, because the rule solution consists exactly of this. The rule solution is not time-consistent $\left(E\left(\pi_{D}\right)>E\left(\pi_{O}\right)\right)$, as we have seen above. The time-consistent solution consists of the discretionary policy, which on average leads to a rate of inflation which is above the rule solution. The rule-based policy, however, is superior to the discretionary policy from the aspect of welfare theory $\left(L_{D}>L_{O}\right)$.

\section{Summary}

In Section C, we have argued that the central bank will become more uncertain about the transmission mechanism as e-money is increasingly used. Hence, the central bank will also become more uncertain about the optimal reaction parameters in the Taylor rule. In the same section, however, we have

\footnotetext{
${ }^{79}$ For the derivation of these findings it is assumed that the money supply is fixed by the government before $\eta$ can be identified.

${ }^{80}$ Optimal here means the best of the alternative rules.
} 
Transitory Effect of Globalization: Increase in Uncertainty 45

also shown that this increase in the uncertainty about the monetary policy transmission mechanism itself tends to decrease the inflation rate. ${ }^{81}$

\section{Policy Implications}

In Sections B and C we have argued that the structural changes (in particular the IT innovations) associated with the globalization process increase the uncertainty about the output and inflation gaps and the transmission mechanism of monetary policy. ${ }^{82}$

What policy implications can be drawn from this? Here we concentrate on some strategic implications. ${ }^{83}$

\footnotetext{
${ }^{81}$ Over and above this, not only the uncertainty with respect to the monetary transmission mechanism increases, but also the transmission mechanism itself changes systematically as globalization leads to open capital markets. The change goes in the direction where the exchange rate channel with respect to the transmission of monetary impulses will become more important. What implications does this have for monetary policy? As economic theory suggests, opening an economy reduces the ability of its monetary policy to affect output, while increasing its effects on inflation (see Karras (1999)). This theoretical prediction has also been supported by empirical results (ibid).

${ }^{82}$ In addition, one could also suppose that globalization increases the complexity of the real economy and, as a consequence, transitorily the central bank has less understanding of the economic structure. Moreover, if the IT-Revolution is actually changing the economic structure itself, the model uncertainty will increase. The question, then, is what consequence this would or should have for monetary policy. The research on this issue, however, has only just begun (see Taylor (1998), Sargent (1999), Hansen and Sargent (2000)), and no clear academic consensus has yet been reached.

${ }^{83}$ We could also add instrumental and institutional implications. For example, in an environment which tends to be prone to changes of mood, monetary policy must have a set of instruments which enables it to steer the provision of central bank money as precisely as possible without giving false and undesired signals. Direct measures appear to be inappropriate in such an environment, and also the room for selective interference of monetary policy becomes smaller through globalization (Issing (1996)). As a consequence, today the operative implementation of monetary policy is based on open market policy worldwide. Another example, which concerns the institutional implications, relates to central bank independence. One could argue that an increase in uncertainty about the monetary policy transmission mechanism would reaffirm the above conclusion (in Section II.C) that reducing central bank independence would be a dangerous route to take. Why? Because, when there is an increase in uncertainty about the transmission mechanism, then the transparency, about what the central bank really does affect, declines. Therefore, the accountability of the central bank vis-à-vis the public, also declines. Thus the public can function less effectively as a corrective against inflation bias tendencies. Hence, short-term pressures by government and other private interest groups on the central bank, to finance public goods or 'election gifts' and to bail out groups or regions hit by adverse shocks, by printing money, may rise, in particular in developing and transitional economies (see Wagner (1999c)). If not compensatable by an increase in transparency through other channels, this can only be resisted by a price-stability-oriented (actually) independent central bank.
} 
46 Transitory Effect of Globalization: Increase in Uncertainty

\section{Policy rules}

When uncertainty about the significance of the indicators and the transmission mechanism of monetary policy increases, the conventional lesson derived from the Brainard rule (1967) tells us that the central bank should become more cautious and thus less active. That is, the central bank's modified reaction function should then typically place less weight on certain variables as their parameters become more uncertain. In our above approach, this means that $\beta$ and $\alpha$ decline. However, it is known that 'Brainard's conservatism principle ${ }^{84}$ is not universally robust, but depends upon the exact form of parameter uncertainty. Recent literature has emphasized circumstances in which parameter uncertainty should lead policy-makers to vary their policy instrument more than would be optimal in the absence of such uncertainty (Smets (1998), Giannoni (1999), Onatski and Stock (1999), Lansing (2000), Meyer, Swanson and Wieland (2001)).

Another issue is economic data uncertainty. It is argued that, for the case of multiple additive uncertainties which require different policy responses, measurement error also requires a more conservative policy reaction (Aoki (1999)). For instance, when the measured value of the rate of inflation increases, it is not clear whether this reflects a supply shock, or a demand shock, or is simply a measurement error. Let us suppose that the objectives of the central bank are not only to prevent inflation but also to maintain the stability of real GDP. In this case, the central bank may make a policy mistake if it substantially increases interest rates because it believes that the increase in the inflation rate is completely due to a demand shock although it is actually because of a measurement error (Bank of Japan (2001)). Accordingly, a central bank may be well advised to keep its monetary policy reaction more 'conservative' than in the case when there is no measurement error.

Moreover, increases in uncertainty about the significance of the indicators and the transmission mechanism of monetary policy could suggest that the central bank should then follow a rule-based policy in order to anchor the expectations of the private sector (and thus to make monetary policy more calculable and to support the price and interest development with a strong

${ }^{84}$ This principle says that uncertainty about key parameters describing the transmission of monetary policy provides a rationale for an 'attenuated' approach to monetary policy-making in the sense of reacting less vigorously to incoming information than would be optimal if such uncertainty did not exist. 
nominal anchor) and to force the central bank into a self-commitment in its monetary policy (see Issing (1996)).

The prior polarization between rules and discretion in a central bank's practices, however, has meanwhile faded away. At least, a 'pure monetary rule' is no longer considered to be an appropriate response to the new challenges of global economic integration. ${ }^{85}$ This trend can also be recognized in the theory of monetary policy, where nowadays more flexible definitions of rules are accepted. This is reflected in definitions such as Taylor's 'rulelike behavior'. Taylor suggests that rule-like behaviour is systematic in the sense of methodical, according to a plan, and not casual or at random (Taylor (1993)). And it also is reflected in a new strand of theory of optimal monetary policy (see Woodford $(1999 \mathrm{~b}, 2000 \mathrm{~b})$ ) which is called timeless perspective mode of monetary policy-making (see McCallum and Nelson (2000), McCallum (2000)).

On the whole, however, the views in the literature about the implications of an increase in uncertainty for monetary policy are non-uniform today. What the ECB (2001) recently has stated to be the key findings of research concerning the appropriate conduct of monetary policy in an uncertain environment, can at most be considered to be the present mainstream view. The ECB emphasizes three aspects: ${ }^{86}$

First, when data or key features of the monetary policy transmission process are subject to uncertainty, the central bank should (under a broad set of circumstances) pursue attenuated and nonactivist policies directed at the medium term.

\footnotetext{
85 "A pure monetary rule, which implies automatism, rigidity and simplicity, would not work in an uncertain environment and would, therefore, be an inappropriate monetary policy response. (...) If the degree of novelty and uncertainty is very high, even contingency rules might not provide an appropriate answer." (Solans (2000, p. 6))

Furthermore, a policy lesson which is sometimes drawn from the fact of uncertain future productivity growth is that when facing a potential shift in productivity growth, central banks should be particularly flexible and operate in a pragmatic fashion when exploring the limits to noninflationary growth. In particular, they should place less emphasis on constructs such as the output gap which depends on assumptions about trend productivity growth (see e.g. IMF, World Economic Outlook 2000, p. 80). The reason is that, in a situation when future productivity growth is highly uncertain, the danger or costs of maintaining an inappropriate policy rise rapidly with time.

${ }^{86}$ An open question is whether all the uncertainties pointed out by the ECB are increased by globalization to the same extent.
} 
48 Transitory Effect of Globalization: Increase in Uncertainty

Second, in the presence of data and model uncertainty, monetary policy should be 'robust'. "This suggests that central banks should not, in general, rely exclusively on any particular individual indicator or model in isolation (be it a particular monetary aggregate, a measure of the output gap or a particular model-based inflation forecast). Instead, central banks need to cross-check information from different sources against the full set of available information." (ECB (2001, p. 50)) Robustness, however, can also mean, to adopt policies which are capable of delivering reasonably good outcomes under a range of alternative plausible models of economic structures.

Third, central banks should try to gain credibility for their monetary policies. Credibility with regard to a well-understood objective is considered to help to provide a clear and reliable anchor for expectations and to reduce strategic uncertainty in the economy.

A precondition for the third requirement, however, is appropriate communication with the public. This is particularly necessary with ongoing globalization. We shall discuss this in more detail in the following.

\section{Transparency and communication}

One of the main vehicles of today's globalization process has been the continuing progress in information technology. Modern information technology, however, has produced the side-effect that today news spreads much faster than a decade or more ago. ${ }^{87}$ This creates a new challenge for the monetary policy or authority, as the actions (and words) of central bank(er)s attract much more and wider-spread attention than before. This calls for extensive communication and transparency of the central banks vis-à-vis the public and the financial markets.

The present two-pillar strategy of the ECB for example may be interpreted as one which fulfills the second of the above-mentioned requirements (robustness), ${ }^{88}$ and, to a lesser extent, the third requirement (credibility). The

\footnotetext{
${ }^{87}$ On the one hand, this tends to create a global convergence of knowledge across certain 'upper-class' or 'educated' groups of various countries. On the other hand, at the same time it produces divergence of knowledge inside countries and across the average-citizens of different countries. The latter statement is based on the presumption that the percentage of 'educated' citizens differs across countries (particularly between industrial and developing countries), and that information alone does not automatically create knowledge. More details of this latter aspect can be found in the following.

${ }^{88}$ However, one may argue that a robust rule must be a simple rule but this two-pillar strategy does not really represent a simple rule.
} 
ECB is reproached for insufficient transparency or communication, in particular by the supporters of an inflation-targeting regime. They contend that (only) 'direct inflation targeting' has a greater degree of transparency and hence a more efficient communication policy of central banks (see Svensson (1997), Bernanke et al. (1998)). Furthermore, they point to the fact that all central banks that practice direct inflation targeting at present explain and justify their policies to a wide public (either voluntarily or because of statutory obligations). Inflation reports are published regularly and exact reasons are given for any deviations from the inflation target. Svensson (1999, p. 626) even claims that " $[t]$ he high degree of transparency and accountability in inflation targeting may then ensure that any concern about the real economy is consistent with the natural-rate hypotheses and therefore reduces, or eliminates, any inflation bias, which arguably translates into an output level target [in the loss function] given by capacity output."

Therefore, switching to direct inflation targeting could be regarded as an appropriate answer to the information technology challenge indicated above. There are, however, some misunderstandings. In standard models of optimal monetary policy, such as Svensson's, transparency is usually identified with the amount or the degree of precision of information that the monetary authority releases to the public. Greater transparency (in this sense) is then widely argued to make monetary policy more predictable as well as more effective and credible in achieving its objectives. Furthermore, it is regarded as facilitating accountability, which in turn can be regarded as a precondition for central bank independence in a democratic society. A recent ECB publication by Winkler (2000), however, has emphasized, very nicely, that transparency should better be defined as the degree of genuine understanding of the monetary policy process and the policy decisions by the public. Assuming that there are frictions in communication or imperfections in the processing of information ${ }^{89}$ more information need not always enhance the 'clarity' of central bank communication. Information has to be processed, structured, condensed, simplified and then put into context in order to become comprehensible.

The costs and benefits of this 'information preparing' activity required for filtering and interpreting information needs to be balanced at the margin in order to use information efficiently. The optimal degree of clarity therefore will differ across different agents and across different decision problems.

\footnotetext{
${ }^{89}$ By comparison, most models of optimal monetary policy discussed in the literature build on presumptions such as perfect rationality, limited uncertainty, homogenous information, common knowledge and frictionless communication (Winkler (2000)).
} 
50 Transitory Effect of Globalization: Increase in Uncertainty

By referring to these arguments, one can come to the conclusion that the presumption, that direct inflation targeting includes a greater degree of transparency and accountability with such favorable conclusions as alleged by Svensson (1999), is partly dependent on the fact that traditional (early) models of direct inflation targeting build on presumptions such as limited uncertainty (ignoring, in particular, model uncertainty) and other simplifications which, as noted earlier, assume away communication issues that are the basis of the alternative definition of transparency used above.

This may be one reason why central banks such as the ECB have refused to take on this concept of direct inflation targeting as the baseline of their strategy, despite all the advantages alleged by the supporters of this strategy. Another reason is that the technical preconditions needed for implementation of direct inflation targeting are often not fulfilled (see Masson et al. (1997), and Wagner (1999b, 2000c)). This is particularly the case in developing and transitional countries.

Nonetheless, all central banks are forced to react to the new challenge coming from the information technology side. The question is: what can or should they do? Experiences with communication problems in the context of the recent decline in the external value of the euro show that saying nothing is often better (less destabilizing) than saying something that is not fully understood in its context. ${ }^{90}$ Or in other words: neither activism in actions nor activism in words is required.

\section{Coming back to a previous aspect: Priorities}

Finally I would like to come back to a point which we have dealt with already in the policy implications section of Section II. There we pointed to the incentives for particular interest groups to urge the central bank to shift its policy focus to stabilizing the economy. ${ }^{91}$ Referring to the Taylor rule above, this would mean that $\beta / \alpha$ should increase. One has to consider, however, that

${ }^{90}$ Moreover, experience with the monetary policy course conducted by Alan Greenspan in the United States appears to show that perhaps things other than transparency are sometimes more important for successful monetary policy, namely authority and reputation and public appearance. This means that gaining reputation for a central bank is path-dependent, and problems may arise if there is a change in leadership, that may change the rules. This fear was one of the reasons for the constructors of the ECB-law to strongly rely on rigid rules.

${ }^{91}$ It is argued that, if inflation declines, the variability of inflation is also limited or decreased by downward nominal rigidities (Holden (2000)). However, a main argument for aiming at a low rate of inflation is precisely that low inflation is associated with lower variability (and thus uncertainty) of inflation (see Fischer (1996)). [Today, avoiding price instability or high inflation variability is the main goal of many central banks (for example, of the ECB), as price instability or 
Transitory Effect of Globalization: Increase in Uncertainty 51

in Section II we have argued that the increase in competition may lead to higher costs of inflation and hence to a change in the government loss function, especially to a reduction of the weight given to output stabilization relative to price level (or inflation) stabilization, $b$. This may also be substantiated by an increase in uncertainty about the monetary transmission mechanism. Hence, the reaction parameter $\beta$ may decline (alternatively $\alpha$ may increase), as it is dependent on the weight that is given to output stabilization in the social/government loss function. Therefore, ceteris paribus, the ratio $\beta / \alpha$ in the reaction function may tend to decrease. ${ }^{92}$

This accords with today's conviction that monetary policy should concentrate on its main task, and this is increasingly supposed to be price stabilization (or prevention of inflation). As we have seen, this is even the case when globalization tends to suppress inflation pressures. This conclusion may even be strengthened if the transmission mechanism of monetary policy becomes more uncertain ${ }^{93}$ even though, as we have seen (in Section III.C), this tends to reduce per se the inflation bias.

high inflation variability is often associated with bad monetary policy. For example, the Maastricht Treaty states that the primary objective of the European Central Bank (ECB) shall be to maintain price stability. It, however, was left to the ECB itself to define price stability, and the ECB has subsequently announced a target of an annual price increase below two percent. As price stability is supposed to imply low inflation variability, it is reasonable that the ECB has chosen a low target for inflation which obviously involves little inflation variability.] Now, as a consequence of the nominal rigidities, variation in nominal demand induces variation in real output, when downward rigidity is binding. Hence, it may appear appropriate to adjust monetary policy with a stronger concentration on output stabilization. And indeed, central banks are often pressured to concentrate, in such a situation, on other targets such as stabilizing output or employment. In Euroland, the Maastricht Treaty, for example, is often interpreted as requiring this from the ECB. Article 2 of the "ECB-law" (Protocol (No. 18) on the Statute of the ESCB and the ECB) states that "the primary objective of the ESCB shall be to maintain price stability. Without prejudice to the objective of price stability, it shall support the general economic policies in the Community..." (see www.ecb.int/about/statescb.htm).

${ }^{92}$ This resembles the recent tendency (Wagner (2000a, b)) that central banks do not (have to) produce as many recessions any more to keep inflation in check. It has been shown that Post-War U.S. recessions have mainly been triggered by restrictive monetary policies to control inflation (Romer and Romer (1994)). Such policy-induced recessions are also regarded as accounting for the continued volatility of the postwar era (Romer (1999)). However, the situation in the United States in the last eight years, in which the Federal Reserve Bank has not initiated a recession out of fear of inflation (as previously) in spite of increasing or sustained overheating trends in the labor market, may serve as a first example for the thesis that globalization (or increased competition) endogenously tends to reduce output variability (see also Gamber and Hung (2001)). In other words, there are fewer recessions and they are less severe if inflation is firmly (brought) under control.

${ }^{93}$ See Issing (1996, p. 308). 



\section{Conclusion}

We have argued in this paper that globalization and the structural changes, which are associated with the globalization process, have two main implications for monetary policy. Firstly, and transitorily, globalization or the structural changes associated with it (including the IT innovations which are the technological basis of today's globalization process) increase uncertainty about the macroeconomic indicators and data and the transmission mechanism of monetary policy. In the context of a Taylor rule, this means, that the uncertainty about the output and inflation gaps, as well as the uncertainty about the monetary transmission mechanism and hence about the optimal reaction parameters, increase. Secondly, globalization increases the locational competition for mobile capital among regions and countries, and hence, with a certain time lag, tends to decrease (suppress) inflation (pressures), as inflation itself is regarded as a locational bad.

This implies that, with ongoing globalization, the role of monetary policy, with respect to price stabilization, may decline. This, however, does not mean that central bankers will have less incentive to fight inflation, because globalization - via the increase in locational competition - also increases the costs of inflation, reflected in the increased danger of a drain of mobile capital in the case of comparatively high(er) inflation (than in competing countries). Nor does it mean that central bankers will have an easy or easier job in the near future, though this may be the case in the long run. In the short to medium term, however, as we have argued, the structural changes associated with the globalization process increase the uncertainty surrounding monetary policy. Therefore, the task of monetary policy for central banks does not become easier.

In this context, it has also to be considered that globalization itself is a controversial process in the eyes of the public. Globalization forces open economies (to a varying extent, depending on the starting conditions) to implement structural reforms, not only in the financial but also in the goods and labor markets, and last but not least in the public sector. ${ }^{94}$ These reforms, however, produce asymmetric costs for different social groups. This is likely

\footnotetext{
${ }^{94}$ In some European countries, this means to bidding farewell to a comfortable social welfare system.
} 
to induce resistance against these reforms and the globalization process in general. In order to avoid a backsliding into isolation, this may force some governments to compensate those social groups which are hurt by the reforms, by social-political measures which are costly. Hence, if not blessed with higher tax revenues from an increase in productivity and thereby in economic growth, ${ }^{95}$ such societies are running into a target conflict because the social-political measures have to be financed, either by an increase in taxes or indebtedness, or by an increase in seigniorage (if not by a reduction of other expenditures). All of these alternatives are locational bads in the international competition process.

In other words, the increase in competition, and the globalization process (which we argued to be the basis for this increase in competition and thereby for a decline in inflation), do not automatically or inevitably last in the long term. ${ }^{96}$ They have to be accompanied by permanent efforts to defend and continue painful structural reforms.

Monetary policy can only play a very limited role here. Nonetheless, monetary authorities should stay alert and try to react in an adequate (sensitive, not-too-activist) way to the (transitorily) increasing uncertainty which we have identified as an essential indirect implication of globalization for monetary policy. By doing this, they can also prepare the way for globalization to create a New Economy which we have defined as a desired situation where high economic growth may be accompanied by low (or no) inflation and low fluctuations in business cycles. Low inflation is a necessary component of such a New Economy. And here, as we have argued, the conditions for the monetary authorities to successfully fight inflation are likely to steadily improve, the more and the longer globalization continues.

\footnotetext{
${ }^{95}$ This is part of the so-called 'New Economy-effects' of globalization expected by optimists.

${ }^{96}$ See O'Rourke (2000) for an analysis of the decline of the so-called first wave of globalization a century ago.
} 


\section{Appendix I: Supplementary Remarks on the Basic Model of Section II.B}

The basic model, which we sketched in Section II.B, assumes the following timing of events:

(1) The 'institutional design stage': We assume that the government itself fixes monetary policy.

(2) The private actors develop their inflation expectations with knowledge of the objective function and of the constraints (and on the basis of information on $y_{n}$ ) but without knowledge of shocks $v$ and $\varepsilon$.

(3) Finally, shocks $v$ and $\varepsilon$ are observable for the government.

(4) With knowledge of these shocks, the government realizes a defined monetary policy, i.e. it fixes $m$ (which leads to a defined $\pi$ and $y$ ). Given the existence of a binding commitment technology, the ex post optimum policy selected in step (4) can only deviate stochastically from a policy which would be optimum on the basis of information and conditions for action in step (1) (ex ante optimum policy). However, if there is no such commitment technology, the ex post optimum policy can also deviate systematically from the ex ante optimum policy.

\section{Optimal rule}

First suppose the policy (rule) is credible and hence enforceable. That is, the policy maker(s) can make a binding commitment to an optimal state-contingent policy rule. The optimal inflation rate can then be derived as being:

$$
\pi_{\mathrm{O}}=\pi *+[b /(1+b)] \varepsilon .
$$

Without a commitment technology, such a policy rule cannot be implemented.

\section{Discretion}

The adequate timing assumption here is the following: policy is chosen under "discretion" when the policy instruments are set at stage (4) above, i.e. after inflation expectations have been formed. To be credible, a policy must now simultaneously fulfill two conditions: the policy must be ex-post optimal (i.e., $d L / d \pi=0$, given $\pi^{\mathrm{e}}$ and $\varepsilon$ ); and expectations must be rational (i.e., $\pi^{\mathrm{e}}=E\left(\pi \mid y_{n}\right)$ ).

The discretionary inflation rate can be derived as:

$$
\pi_{D}=\pi *+b\left(y^{*}-y_{n}\right)+[b /(1+b)] \varepsilon .
$$

When we compare (5) and (6), we see that there is an inflation bias: $b\left(y^{*}-y_{n}\right)$ with discretionary policy (whereas the employment outcome remains the same as in the case of the optimal policy rule above, namely $y=y_{n}-[1 /(1+b)] \varepsilon$ in both cases). 



\section{Appendix II: Derivations of Equations (21) and (22) in Section III.C}

\section{Derivation of equation (21):}

The above core model discussed in Section III.C consists of the equations (1), (2), (3a) and (4).

The timing of events is:

$$
\pi^{\mathrm{e}} \text {------ } \varepsilon, v \text {------ } \pi \text {------- } \eta \text {. }
$$

That is, money supply is fixed by the monetary authority before $\eta$ can be observed. However, $v$ and $\varepsilon$ can be observed by the monetary authority, but they do not have any information content with respect to the multiplier uncertainty. Therefore, after using the expectations operator on equation (3a) and noting that $E(\eta)=1$ and $\sigma_{\mathrm{m} \eta}=0$, we have:

$$
E(\pi)=E(\eta) \cdot E(m)+\sigma_{m \eta}=E(m) \text { and thus } \pi^{\mathrm{e}}=m^{e} .
$$

Inserting this into equation (2) and calculating $y-y^{*}$ and $\pi-\pi^{*}$, we get

$$
L=E\left\{0,5\left[\left(\eta m+v-\pi^{*}\right)^{2}+b\left(y_{n}-y^{*}+\eta m+v-m^{e}-\varepsilon\right)^{2}\right]\right\}
$$

or

$$
L=0,5\left[\left(\eta m+v-\pi^{*}\right)^{2}+b\left(y_{n}-y^{*}+\eta m+v-m^{e}-\varepsilon\right)^{2}\right]+\lambda\left[m^{e}-E m\right]
$$

where $\lambda=$ a Lagrange multiplier for the condition that expectations are rational.

Differentiation gives:

$$
\begin{gathered}
\left.\frac{\delta L}{\delta m}\right|_{m=E(m)}=\eta\left(\eta m+v-\pi^{*}\right)+\eta b\left(y_{n}+\eta m-m^{e}+v-\varepsilon-y^{*}\right)-\lambda \\
\frac{\delta L}{\delta m^{e}}=-b\left(y_{n}+\eta m-m^{e}+v-\varepsilon-y^{*}\right)+\lambda
\end{gathered}
$$

To calculate the rationally expected money growth rate, first the expectation values of the first order conditions have to be constructed.

From $E\left(\frac{\delta L}{\delta m^{e}}\right)=0$ one gets: $\lambda=b\left(y_{n}-y^{*}\right)$.

Inserting this into the expectations value of $E\left(\frac{\delta L}{\delta m}\right)=0$ then gives: 
58 Appendix II

$$
E(m)=m^{e}=\pi^{*} /\left[1+(1+b) \sigma_{\eta}^{2}\right]=\pi_{0}^{\mathrm{e}}
$$

Substituting (29) back into (27) and calculating the ex-post first order condition, $E\left(\frac{\delta L}{\delta m} \mid \varepsilon, v\right)=0$, then gives:

and thus

$$
m_{O}=\frac{\eta \pi^{*}}{1+(1+b) \sigma_{\eta}^{2}}+\frac{\eta b \varepsilon+(1+b)\left(1+\sigma_{\eta}^{2}-\eta\right) v}{(1+b)\left(1+\sigma_{\eta}^{2}\right)}
$$

$$
\pi_{\mathrm{O}}=\frac{\eta \pi^{*}}{1+(1+b) \sigma_{\eta}^{2}}+\frac{\eta b \varepsilon+(1+b)\left(1+\sigma_{\eta}^{2}-\eta\right) v}{(1+b)\left(1+\sigma_{\eta}^{2}\right)}
$$

\section{Derivation of equation (22):}

One gets equation (22) by calculating the expectations value of equation (27) noting that the last term $\lambda$ is suppressed.

Instead of equation (29) one then gets

$$
E(m)=m^{e}=\left[\pi^{*}+b\left(y^{*}-y_{n}\right)\right] /\left[1+(1+b) \sigma_{\eta}^{2}\right]=\pi_{D}^{\mathrm{e}}
$$

Substituting this back into (27) and calculating the ex-post first order condition then gives:

$$
\pi_{D}=\pi_{O}+\frac{\eta b\left(y^{*}-y_{n}\right)}{1+(1+b) \sigma_{\eta}^{2}}
$$




\section{References}

Alba, P., A. Bhattacharya, S. Claessens, S. Ghosh, and L. Hernandez, 1998, "Volatility and Contagion in a Financially-Integrated World: Lessons from East Asia's Recent Experience", mimeo.

Alesina, A., and A. Drazen, 1991, "Why are Stabilizations Delayed?", American Economic Review 81, pp. 1170-1188.

Alesina, A., and R. Gatti, 1995, “Independent Central Banks: Low Inflation at No Cost?", American Economic Review 85, pp. 196-200.

Aoki, K., 1999, “On the Optimal Monetary Policy Response to Noisy Indicators”, mimeo, Princeton University.

Autschbach, J., 1997, Internationale Standortwahl, Wiesbaden: Deutscher UniversitätsVerlag.

Baldwin, R., and P. Krugman, 2000, "Agglomeration, Integration and Tax Harmonization” Centre for Economic Policy Research, Discussion Paper 2630.

Ball, L., 1997, "Efficient Rules for Monetary Policy”, NBER Working Paper No. 5952.

Ball, L., 1999, "Policy Rules for Open Economies", in: J.B. Taylor (ed.), Monetary Policy Rules, Chicago and London, The University of Chicago Press, pp. 127-56.

Ball, L., 2000, "Policy Rules and External Shocks", NBER Working Paper 7910.

Bank of Japan, 2001, “Technological Innovation and Banking Industry/Monetary Policy: Forum on the Development of Electronic Payment Technologies and Its Implications for Monetary Policy, Report”, Bank of Japan IMES Discussion Paper No. 2001-E-3.

Barro, R.J., 1997, Determinants of Economic Growth. A Cross-Country Empirical Study, Cambridge, Massachusetts: MIT Press.

Barro, R.J., and D.B. Gordon, 1983, "Rules, Discretion, and Reputation in a Model of Monetary Policy”, Journal of Monetary Economics 12, pp. 101-20.

Berg, A., 1999, "The Asia Crisis: Causes, Policy Responses, and Outcomes" IMF Working Paper 99/138, Washington: International Monetary Fund.

Berger, W., 2001, Die Entstehung und Ausbreitung von Währungskrisen, Ph.D. thesis, University of Hagen.

Bernanke, B.S., and M. Gertler, 1995, "Inside the Black Box: The Credit Channel of Monetary Policy Transmission", Journal of Economic Perspectives 9, pp. 27-48.

Bernanke, B.S., and M. Gertler, 1999, "Monetary Policy and Asset Price Volatility", in: New Challenges for Monetary Policy: A Symposium Sponsored by the Federal Reserve Bank of Kansas City, Federal Reserve Bank of Kansas City, pp. 77-128. Also in Federal Reserve Bank of Kansas City Economic Review, Fourth Quarter 1999, pp. 17-51.

Bernanke, B.S., T. Laubach, F.S. Mishkin, and A.S. Posen, 1998, Inflation Targeting: Lessons from the International Experience, Princeton, New Jersey: Princeton University Press. 
60 References

Blinder, A.S., 1998, Central Banking in Theory and Practice, Cambridge, Massachusetts: MIT Press.

Bootle, R., 1996, The Death of Inflation. Surviving and Thriving in the Zero Era, London: Nicholas Brealey.

Brainard, W., 1967, "Uncertainty and the Effectiveness of Policy", American Economic Review 57, pp. 411-25.

Brash, D.T., 2000, "How Should Monetary Policy Makers Respond to the New Challenges of Global Economic Integration", presented at the Symposium on Global Economic Integration: Opportunities and Challenges sponsored by the Federal Reserve Bank of Kansas City, Jackson Hole, Wyoming, August 24-26.

Buiter, W., 2000, “The New Economy and Old Monetary Economics”, Discussion Paper, Bank of England.

Calmfors, L., 1998, "Macroeconomic Policy, Wage Setting and Employment - What Difference Does the EMU Make?", Oxford Review of Economic Policy, Vol. 3 (Autumn 2), pp. 125-51.

Calvo, G.A., and C.M. Reinhart, 2000, "Fear of Floating”, NBER Working Paper 7993.

Cecchetti, S.G., H. Genberg, J. Lipski, and S. Wadhwani, 2000, “Asset Prices and Central Bank Policy”, Geneva Reports on the World Economy, Vol. 2, Geneva: International Center for Monetary and Banking Studies; London: Centre for Economic Policy Research.

Chang, R., 2001, "Commitment, Coordination Failures, and Delayed Reforms", Journal of Monetary Economics 47, pp. 123-44.

Chang, R., and A. Velasco, 2000, "Exchange Rate Policy for Developing Countries", American Economic Review Papers and Proceedings 90, pp. 71-75.

Citrin, D., and S. Fischer, 2000, "Meeting the Challenges of Globalization in the Advanced Economies", in: H. Wagner (ed.), Globalization and Unemployment, Berlin: Springer, pp. 19-35.

Clarida, R., J. Gali, and M. Gertler, 1999, "The Science of Monetary Policy: A New Keynesian Perspective”, Journal of Economic Literature 37, pp. 1661-707.

Cogley, T., 1999, "Should the Fed Take Deliberate Steps to Deflate Asset Price Bubbles?", Federal Reserve Bank of San Francisco Economic Review No. 1, pp. 42-52.

Cukierman, A., 1998, "The Economics of Central Banking", in Wolf, H.C. (ed.), Contemporary Economic Issues: Proceedings of the Eleventh World Congress of the International Economic Association, Tunis, Volume 5, Macroeconomics and Finance, New York, St. Martin's Press, London, Macmillan Press, pp. 37-82.

Cukierman, A., S. Edwards and G. Tabellini, 1992, "Seignorage and Political Instability", American Economic Review 82, pp. 537-55.

Drazen, A., 2000, Political Economy in Macroeconomics, Princeton, New Jersey: Princeton University Press.

ECB, 2001, "Monetary Policy-Making Under Uncertainty", ECB, Monthly Bulletin, January 2001, pp. 43-55.

Ehrmann, M., and F. Smets, 2000, "Uncertain Potential Output: Implications for Monetary Policy”, Discussion Paper European Central Bank. 
Eichengreen, B., P. Masson, M. Savastano, and S. Sharma, 1999, "Transition Strategies and Nominal Anchors on the Road to Greater Exchange Rate Flexibility", Essays in International Finance, No. 213, Princeton, New Jersey: Princeton University Press.

Eijffinger, S.C.W., and M. Hoeberichts, 1998, "The Trade off Between Central Bank Independence and Conservativeness", Oxford Economic Papers 50, pp. 397-411.

Evans, G.W., 1986, “A Test for Speculative Bubbles in the Sterling-Dollar Exchange Rate: 1981-84", American Economic Review 76, pp. 621-36.

Feldstein, M., 1997, "The Costs and Benefits of Going from Low Inflation to Price Stability", in: Romer, Ch.D. and D.H. Romer (eds.), Reducing Inflation. Motivation and Strategy, Chicago: University of Chicago Press, pp. 123-66.

Feldstein, M., (ed.) 1999, The Costs and Benefits of Price Stability, Chicago: University of Chicago Press.

Feldstein, M., 2000, “Aspects of Global Economic Integration: Outlook for the Future”, presented at Symposium on Global Economic Integration: Opportunities and Challenges sponsored by the Federal Reserve Bank of Kansas City, Jackson Hole, Wyoming, August 24-26.

Fischer, S., 1991, "Growth, Macroeconomics, and Development", NBER Working Paper 3702 .

Fischer, S., 1993, “The Role of Macroeconomic Factors in Economic Growth”, Journal of Monetary Economics 32, pp. 485-512.

Fischer, S., 1996, "Why are Central Banks Pursuing Long-Run Price Stability?", in: Federal Reserve Bank of Kansas City (ed.), Achieving Price Stability, Kansas City, pp. 7-34.

Fischer, S., 1999, "Reforming the International Financial System", Economic Journal 109 , pp. 557-576.

Fischer, S., 2001, “Exchange Rate Regimes: Is the Bipolar View Correct?”, Distinguished Lecture on Economics in Government, delivered at the Meetings of the American Economic Association, New Orleans, January 6, 2001. http://www.imf.org/external/np/speeches/2001.

Fischer, S., and F. Modigliani, 1978, "Towards an Understanding of the Real Effects and Costs of Inflation”, Weltwirtschaftliches Archiv 94, pp. 810-33.

Frankel, J.A., 1999, "No Single Currency Regime is Right for all Countries or at all Times", Essays in International Finance No. 215, Princeton University International Finance Section.

Friedman, B.M., 1999, “The Future of Monetary Policy: The Central Bank as an Army with Only a Signal Corps?”, International Finance, No. 2 (November), pp. 321-38, and NBER Working Paper 7420.

Friedman, B.M., 2000, "Decoupling at the Margin: The Threat to Monetary Policy from the Electronic Revolution in Banking", NBER Working Paper 7955.

Furman J., and J.E. Stiglitz, 1998, "Economic Crisis: Evidence and Insights from East Asia", Brookings Papers on Economic Activity, No. 2, pp. 1-133.

Gamber, E.N., and J.H. Hung, 2001, "Has the Rise in Globalization Reduced U.S. Inflation in the 1990s?", Economic Inquiry 39, pp. 58-73. 
Giannoni, M., 1999, "Does Model Uncertainty Justify Caution? Robust Optimal Monetary Policy in a Forward-Looking Model", mimeo, New Jersey: Princeton University.

Goodfriend, M., 2000, "Financial Stability, Deflation, and Monetary Policy", Bank of Japan, IMES Discussion Paper No. 2000-E-27.

Goodhart C.A.E., 2000, “Can Central Banking Survive the IT Revolution?”, presented at World Bank: Future of Monetary Policy and Banking Conference, Washington: The World Bank.

Hamermesh, D.S., and G.A. Pfann, 1996, “Adjustment Costs in Factor Demand”, Journal of Economic Literature 34, pp. 1264-92.

Hansen, L., and T. Sargent, 2000, "Wanting Robustness in Macroeconomics", Ninth International Conference, Institute for Monetary and Economic Studies, Japan, Tokyo: Bank of Japan.

Holden, S., 2000, "Monetary Policy and Nominal Rigidities", Unpublished paper, University of Oslo, http://www.uio.no/sholden.

IMF 1997, Globalization - Opportunities and Challenges, World Economic Outlook, (May), Washington: International Monetary Fund.

IMF 2000, World Economic Outlook, September, Washington: International Monetary Fund.

Issing, O., 1996, “Geldpolitik in einer Welt globalisierter Finanzmärkte”, Aussenwirtschaft 51, Heft III, pp. 295-309.

Issing, O., 1999, "The Monetary Policy of the ECB in a World of Uncertainty", contribution to the Policy Panel at the Conference on Monetary Policy-Making under Uncertainty, European Central Bank.

Iwd, 1999, "Globalisierung macht stark", in: iwd Nr. 47, (25 November), pp. 4-5.

Jensen, H., 1999, “Targeting Nominal Income Growth or Inflation?”, Working Paper, University of Copenhagen.

Judson, R., and A. Orphanides, 1996, "Inflation, Volatility, and Growth, Finance and Economics", Discussion Paper No. 96/16, Board of Governors of the Federal Reserve System.

Karras, G., 1999, "Openness and the Effects of Monetary Policy", Journal of International Money and Finance 18, pp. 13-26.

Kent, C., and P. Lowe, 1997, “Asset-Price Bubbles and Monetary Policy”, Reserve Bank of Australia, Research Discussion Paper No. 9709.

Kißmer, F., 2001, “Globalisierung, Reformstau und New Economy”, mimeo, University of Hagen.

Knight, F.H., 1921, “Risk, Uncertainty, and Profit”, New York 1964.

Lane, P.R., 1997, “Inflation in Open Economies”, Journal of International Economics 42, pp. $327-47$.

Lansing, K., 2000, "Learning About a Shift in Trend Output: Implications for Monetary Policy and Inflation", presented at the conference on Structural Change and Monetary Policy held on March 3-4, 2000, sponsored by Federal Reserve Bank of San Francisco and SIEPR. 
Letterie, W., and F. Lippi, 1999, “Credibility and Imperfect Monetary Control”, Chapter I-II in: Lippi, F. (1999), Central Bank Independence, Targets and Credibility: Political and Economic Aspects of Delegation Arrangements for Monetary Policy, Cheltenham, U.K. and Northampton, Massachusetts: Elgar, pp. 23-39.

Lippi. F., 1998, "On Central Bank Independence and the Stability of Policy Targets", Scandinavian Journal of Economics 100, pp. 495-512.

Lohmann, S., 1992, "Optimal Commitment in Monetary Policy: Credibility versus Flexibility", American Economic Review 82, pp. 273-86.

Lorz, J.O., 1997, Standortwettbewerb bei internationaler Kapitalmobilität - Eine modelltheoretische Untersuchung, Kieler Studien 284, Tübingen: Mohr, 342.

Ludvigson, S. and C. Steindel, 1999, "How Important is the Stock Market Effect on Consumption", Federal Reserve Bank of New York, Economic Policy Review, Vol. 2 No. 5, pp. 29-52.

Mankiw, N.G., 1999, Macroeconomics, 4. ed., New York: Worth Publishers.

Masson, P.R., M.A. Savastano, and S. Sharma, 1997, “The Scope for Inflation Targeting in Developing Countries”, IMF Working Paper No. 97/130, Washington: International Monetary Fund.

McCallum, B.T., 1995, “Two Fallacies Concerning Central Bank Independence”, American Economic Review Papers and Proceedings 85, pp. 207-11.

McCallum, B.T., 1997a, "Crucial Issues Concerning Central Bank Independence", Journal of Monetary Economics 39, 99-112.

McCallum, B.T., 1997b, “The Alleged Instability of Nominal Income Targeting”, Reserve Bank of New Zealand Discussion Paper, August.

McCallum, B.T., 2000, “The Present and Future of Monetary Policy Rules", NBER Working Paper No. 7916.

McCallum, B.T., and E. Nelson, 1997, “An Optimizing IS-LM-Specification for Monetary Policy and Business Cycle Analysis", NBER Working Paper No. 5875.

McCallum, B.T., and E. Nelson, 2000, "Timeless Perspectives Discretionary Monetary Policy in Forward-Looking Models”, NBER Working Paper No. 7915.

Meyer, L.H., 2000, "Structural Change and Monetary Policy", Speech before the Joint Conference of the Federal Reserve Bank of San Francisco and the Stanford Institute for Economic Policy Research, San Francisco, California, 3, 2000. http://www.frbsf.org/economics/conferences/000303/agenda.html

Meyer, L.H., E.T. Swanson, and V.W. Wieland, 2001, "NAIRU Uncertainty and Nonlinear Policy Rules", mimeo, Washington, D.C.: Federal Reserve Bank.

Mussa, M., P. Masson, A. Swoboda, E. Jadresic, P. Mauro, and A. Berg, 2000, "Exchange Rate Regimes in an Increasingly Integrated World Economy", IMF Occasional Paper No. 193, Washington: International Monetary Fund.

O’Rourke, K.H., 2000, “Globalization in Historical Perspective”, in: H. Wagner (ed.), Globalization and Unemployment, Berlin: Springer, pp. 39-53.

Obstfeld, M., 2000, "Globalization and Macroeconomics", NBER Reporter, (Fall), pp. 18-23. 


\section{References}

Okina, K., 1984, "Rational Expectations, Bubbles and Foreign Exchange Market”, Bank of Japan Monetary and Economic Studies 2, pp. 81-118.

Okina, K., M. Shirakawa and S. Shiratsuka, 1999, "Financial Market Globalization: Present and Future", Bank of Japan Monetary and Economic Studies Vol. 3 No. 17, pp. 1-40.

Onatski, A., and J.H. Stock, 1999, "Robust Monetary Policy Under Model Uncertainty in a Small Model of the U.S. Economy", presented at the conference on Monetary Policy and Monetary Institutions held on March 5-6, 1999, sponsored by Federal Reserve Bank of San Francisco and SIEPR.

Orphanides, A., 1998, "Monetary Policy Evaluation With Noisy Information”, Finance and Economics Discussion Series, Working Paper No. 1998-50. Board of Governors of the Federal Reserve System.

Orphanides, A., 2000, “The Quest for Prosperity Without Inflation, European Central Bank", Working Paper No 15.

Ortiz, G., 2000, Panel Contribution (paper) on "How Should Monetary Policy Makers Respond to the New Challenges of Global Economic Integratio?", Symposium on Global Economic Integration: Opportunities and Challenges sponsored by the Federal Reserve Bank of Kansas City, Jackson Hole, Wyoming, (August), pp. 24-26.

Parker, J., 2000, "Spendthrift in America? On Two Decades of Decline in the U. S. Saving Rate", in: B. Bernanke and J. Rotemberg (eds.), NBER Macroeconomics Annual, Cambridge, Massachusetts.

Persson, T., and G. Tabellini, 1999, "Political Economics and Macroeconomic Policy", in: Taylor, J. and M. Woodford, (eds.), Handbook of Macroeconomics, Amsterdam: Elsevier, pp. 1397-1482.

Reinhart, C.M., 2000, “The Mirage of Floating Exchange Rates", American Economic Review 90, pp. 65-70.

Remsperger, H., 2000, “Globalisierung und Finanzmärkte, Vortrag beim Wirtschaftsforum über Probleme und Perspektiven der Globalisierung", in Essen, am 8. Juni 2000, and in Deutsche Bundesbank, Auszüge aus Presseartikeln, No. 30, pp. 2-6.

Rodrik, D., 1997, Has Globalization Gone Too Far?, Washington: Institute for International Economics.

Rogoff, K., 1985, "The Optimal Degree of Commitment to an Intermediate Monetary Target", Quarterly Journal of Economics 100, pp. 1169-90.

Romer, C., 1999, "Changes in Business Cycles: Evidence and Explanations", Journal of Economic Perspectives 13, pp. 23-44.

Romer, C., and D. Romer, 1994, "Monetary Policy Matters", Journal of Monetary Economics 34, pp. 75-88.

Romer, D., 1993, “Openness and Inflation: Theory and Evidence", Quarterly Journal of Economics 108, pp. 869-903.

Rudebusch, G., 1999, "Is the Fed too Timid? Monetary Policy in an Uncertain World”, Federal Reserve Bank of San Francisco, Working Paper No. 99-05.

Saint-Paul, G., 1996, "Exploring the Political Economy of Labor Market Institutions", Economic Policy 23, pp. 263-315. 
Sargent, T., 1999, “Comment on 'Policy Rules for Open Economies”, in: J. Taylor (ed.), Monetary Policy Rules, Chicago: University of Chicago Press.

Shiller, R.J., 1997, “Why Do People Dislike Inflation?", in: C.D. Romer and D.H. Romer (eds.), Reducing Inflation. Motivation and Strategy, Chicago: University of Chicago Press, pp. 13-65.

Shiratsuka, S., 2000, "Is There a Desirable Rate of Inflation? A Theoretical and Empirical Survey”, Bank of Japan IMES Discussion Paper No. 2000-E-32.

Siebert, H., (ed.) 1995, Locational Competition in the World Economy, Tübingen: Mohr Siebeck.

Siebert, H., 1996, "On the Concept of Locational Competition”, Kieler Arbeitspapiere 731, Kiel.

Siebert, H., 2000, Zum Paradigma des Standortwettbewerbs, Tübingen: Mohr Siebeck.

Smets, F., 1998, “Output Gap Uncertainty: Does It Matter for the Taylor Rule?”, BIS Working Paper 60.

Solans, E.D., 2000, Panel Contribution (paper) on: "How Should Monetary Policy Makers Respond to the New Challenges of Global Economic Integration?", presented at Symposium "Global Economic Integration: Opportunities and Challenges" sponsored by the Federal Reserve Bank of Kansas City, Jackson Hole, Wyoming, August 24-26.

Svensson, L.E.O., 1997, "Inflation Forecast Targeting: Implementing and Monitoring Inflation Targets", European Economic Reviews 41, pp. 1111-1146.

Svensson, L.E.O., 1999, "Inflation Targeting as a Monetary Policy Rule", Journal of Monetary Economics 43, pp. 607-654.

Svensson, L.E.O., and M. Woodford, 2000, "Indicator Variables for Optimal Monetary Policy”, European Central Bank Working Paper No 12.

Swanson, E., 2000, "On Signal Extraction and Non-Certainty-Equivalence in Optimal Monetary Policy Rules”, Finance and Economics Discussion Series, Federal Reserve Board, Washington, D.C.

Taylor, J.B., 1993, "Discretion Versus Policy Rules in Practice", Carnegie-Rochester Series on Public Policy 39, pp. 195-214.

Taylor, J. B., 1998, "Information Technology and Monetary Policy", Bank of Japan Monetary and Economic Studies 16, 1, pp. 9-28.

UNCTAD, 1999, World Investment Report - Foreign Direct Investment and the Challenge of Development, New York and Geneva.

Vickers, J., 1998, "Inflation Targeting in Practice: The UK Experience", Bank of England Quarterly Bulletin 38, pp. 368-375.

Vickers, J., 1999, "Monetary Policy and Asset Prices", Bank of England Quarterly Bulletin 39, pp. 428-435.

Vickers, J., 2000, "Monetary Policy and the Supply Side", mimeo, Bank of England.

Wadhwani, S., 2000, "The Impact of the Internet on UK Inflation", speech delivered at the London School of Economics, 23 February. http://www.bankofengland.co.uk/speeches/speaker.htm\#/wadhwani

Wagner, H., 1983, Inflation und Wirtschaftswachstum, Berlin: Duncker \& Humblot. 
Wagner, H., 1997, Wachstum und Entwicklung. Theorie der Entwicklungspolitik, 2. ed., München: Oldenbourg.

Wagner, H., 1998, "Central Banking in Transition Countries", IMF Working Paper 98/126, Washington, DC.

Wagner, H., 1999a, Einführung in die Weltwirtschaftspolitik, 4. ed., München: Oldenbourg.

Wagner, H., 1999b, "Inflation Targeting versus Monetary Targeting”, Kredit und Kapital 32, pp. 610-632.

Wagner, H., 1999c, "Central Bank Independence and the Lessons for Transition Economies from Developed and Developing Countries", Comparative Economic Studies 41 (4), pp. 1-22.

Wagner, H., 2000a, “Globalization and Inflation”, in: H. Wagner (ed.), Globalization and Unemployment, Berlin: Springer, pp. 345-390.

Wagner, H., 2000b, "Effects of Globalization on National Monetary Policy," in: A. Karmann (ed.), "Financial Systems and Stability", Heidelberg/New York: Physica, pp. 34-56.

Wagner, H., 2000c, "Controlling Inflation in Transition Economies: On the Relevance of Central Bank Independence and the Right Nominal Anchor", Atlantic Economic Journal 27, pp. 60-70.

Wagner, H., 2000d, "Which Exchange Rate Regimes in an Era of High Capital Mobility?", North American Journal of Economics and Finance 11, pp. 191-203.

Wagner, H., 2000e, "Central Banking in Transition Countries", Eastern European Economics 38 (4), pp. 6-53.

Wagner, H., 2000f, Stabilitätspolitik. Theoretische Grundlagen und institutionelle Alternativen, 6. ed., München: Oldenbourg.

Walsh, C. E., 1995, “Optimal Contracts for Central Bankers", American Economic Review 85 , pp. $150-167$.

Wildasin, D.E., 2000, "Factor Mobility and Fiscal Policy in the EU: Policy Issues and Analytical Approaches", Economic Policy 31, pp. 337-378.

Winkler, B., 2000, "Which Kind of Transparency? On the Need for Clarity in Monetary Policy-Making”, European Central Bank Working Paper No. 26.

Woodford, M., 1999a, "Optimal Monetary Policy Inertia", Manchester School Supplement, pp. 1-35; also NBER Working Paper 7261.

Woodford, M., 1999b, "Commentary: How Should Monetary Policy Be Conducted in an Era of Price Stability?", New Challenges for Monetary Policy: A Symposium Sponsored by the Federal Reserve Bank of Kansas City. Federal Reserve Bank of Kansas City, pp. 277-316.

Woodford, M., 2000a, "Monetary Policy in a World Without Money", International Finance, 3 (2), pp. 229-260.

Woodford, M., 2000b, "Pitfalls of Forward-Looking Monetary Policy", American Economic Review Papers and Proceedings 90, pp. 100-104. 


\section{SUERF - \\ Société Universitaire Européenne de Recherches Financières}

SUERF is incorporated in France as a non-profit-making Association. It was founded in 1963 as a European-wide forum with the aim of bringing together professionals from both the practitioner and academic sides of finance who have an interest in the working of financial markets, institutions and systems, and the conduct of monetary and regulatory policy.

SUERF is a network association of central bankers, bankers and other practitioners in the financial sector, and academics with the purpose of analysing and understanding European financial markets, institutions and systems, and the conduct of regulation and monetary policy. It organises regular Colloquia, lectures and seminars and each year publishes several analytical studies in the form of SUERF Studies.

SUERF has its full-time permanent Executive Office and Secretariat located at the Austrian National Bank in Vienna. It is financed by annual corporate and personal membership fees. Corporate membership currently includes major European financial institutions and Central Banks. SUERF is strongly supported by Central Banks in Europe and its membership comprises most of Europe's Central Banks (29 in total, including the Bank for International Settlements and the European Central Bank), banks, other financial institutions and academics.

\section{SUERF STUDIES}

1. G.M.M. Gelauff and C. den Broeder, Governance of Stakeholder relationships; The German and Dutch experience, Amsterdam, 1997, ISBN 90-5143-024-8.

2. Rolf Skog, Does Sweden need a Mandatory Bid Rule, a critical analysis, Amsterdam 1997, ISBN 90-5143-025-6.

3. Corporate Governance in Central and Eastern Europe; Transition Management is a Tough Job. Two papers. Amsterdam, 1998, ISBN 90-5143-027-2.

1) Debora Revoltella, Financing Firms in East European Countries: An Asymmetric Information and Agency Costs Approach

2) Peter H. Haiss and Gerhard Fink, Seven Years of Financial Market Reform in Central Europe 
4. Joseph Bisignano, Towards an Understanding of the Changing Structure of Financial Intermediation; An Evolutionary Theory of Institutional Survival, Amsterdam, 1998, ISBN 90-5143-026-4. (out of print)

5. David T. Llewellyn, The New Economics of Banking, Amsterdam, 1999, ISBN 90-5143-028-0.

6. John Calverley, Sarah Hewin, Kevin Grice, Emerging Stock Markets after the Crisis, Amsterdam, 2000, ISBN 90-5143-029-9.

7. Strengthening Financial Infrastructure: Deposit Insurance and Lending of Last Resort (two contributions), Amsterdam, 2000, ISBN 90-5143-030-2.

1) Richard Dale, Deposit Insurance in Theory and Practice

2) Christian de Boissieu and Franco Bruni, Lending of Last Resort and Systemic Stability in the Eurozone.

8. Cem Karacadag and Michael W. Taylor, The New Capital Adequacy Framework: Institutional Constraints and Incentive Structures, Vienna, 2000, ISBN 3-902109-00-9.

9. Miguel Sebastián and Carmen Hernansanz, The Spanish Banks' Strategy in Latin America, Vienna, 2000, ISBN 3-902109-01-7.

10. M.M.G. Fase and W.F.V. Vanthoor, The Federal Reserve System Discussed: A Comparative Analysis, Vienna, 2000, ISBN 3-902109-02-5.

11. Willem H. Buiter and Clemens Grafe, Central Banking and the Choice of Currency Regime in Accession Countries, Vienna, 2001, ISBN 3-902-109-03-3.

12. Sanjiva Prasad, Christopher J. Green, and Victor Murinde, Company Financing, Capital Structure, and Ownership: A Survey, and Implications for Developing Economies, Vienna, 2001, ISBN 3-902109-04-1.

13. Martin M.G. Fase, Investment in Paintings: The interaction of monetary return and psychic income, Vienna, 2001, ISBN 3-902109-05-X.

14. Alexandre Lamfalussy, Reflections on the Regulation of European Securities Markets, Vienna 2001, ISBN 3-902109-06-8.

15. Italian Mutual Banks: Performance, Efficiency and Mergers and Acquisitions (two contributions), Vienna 2002, ISBN 3-902109-07-6.

1) Juan Sergio Lopez, Alessandra Appennini, Stefania P.S. Rossi, Evidence from two different cost frontier techniques.

2) Roberto Di Salvo, Maria Carmela Mazzilis, Andrea Guidi, Mergers and acquisitions between mutual banks in Italy: an analysis of the effects on performance and productive efficiency.

16. Thomas Reininger, Franz Schardax, Martin Summer, Financial System Transition in Central Europe: The First Decade, Vienna 2002, ISBN 3-902109-08-4 